\title{
Clinical trials and progress with paclitaxel in ovarian cancer
}

\author{
This article was published in the following Dove Press journal: \\ International Journal of Women's Health \\ 18 November 2010 \\ Number of times this article has been viewed
}

\section{Sanjeev Kumar' \\ Haider Mahdi ${ }^{2}$ \\ Christopher Bryant ${ }^{\prime}$ \\ Jay P Shah' \\ Gunjal Garg \\ Adnan Munkarah ${ }^{4}$ \\ 'Department of Obstetrics and Gynecology, Wayne State University School of Medicine and Karmanos Cancer Institute Detroit, Michigan; ${ }^{2}$ Department of Obstetrics and Gynecology, University of Washington, Seattle, Washington; ${ }^{3}$ Department of Obstetrics and Gynecology, University of Michigan Comprehensive Cancer Center, Ann Arbor, Michigan; \\ ${ }^{4}$ Department of Obstetrics and Gynecology, Henry Ford Hospital, Detroit, Michigan, USA}

Correspondence: Sanjeev Kumar Department of Obstetrics and Gynecology, Wayne State University, 3990 John R, 7 Brush North, Hutzel Women's Hospital, Detroit, MI 4820I, USA

Tel +I 248924 |79|

Email skumar@med.wayne.edu
Abstract: Paclitaxel is a front-line agent for ovarian cancer chemotherapy, along with the platinum agents. Derived from the Pacific yew tree, Taxus brevifolia, paclitaxel has covered significant ground from the initial discovery of its antineoplastic properties to clinical applications in many forms of human cancers, including ovarian cancer. Although much has been published about the unique mechanism of action of this agent, several issues remain to be resolved. Finding the appropriate dosage schedule for paclitaxel in chemo-naïve and recurrent ovarian cancer, defining the role of paclitaxel in maintenance chemotherapy, and elucidating the mechanisms of taxane resistance are areas of intense research. Newer forms of taxanes are being manufactured to avoid troublesome adverse effects and to improve clinical efficacy. These issues are reviewed in detail in this paper with an emphasis on clinically relevant evidence-based information.

Keywords: paclitaxel, clinical trials, ovarian cancer, treatment

\section{Epithelial ovarian cancer}

Epithelial ovarian cancer is the leading cause of death from gynecologic cancer in the US. An estimated 21,650 new cases and 15,520 deaths were attributed to ovarian cancer, representing $6 \%$ of all cancer deaths recorded in the US in $2008 .{ }^{1}$ One woman in 70 will develop ovarian cancer, and one woman in 100 will die of the disease. ${ }^{1,2}$ The incidence of ovarian cancer increases with age. There is a particularly steep rise in incidence starting from the fifth decade of life, peaking in the eighth decade.

Serous carcinoma is the most common histologic type of ovarian cancer in all racial and ethnic groups, followed by mucinous, endometrioid, and clear cell carcinoma. ${ }^{2}$ Transitional, mixed, and undifferentiated histology are the uncommon types of ovarian cancer. Symptoms of the disease are nonspecific and there are no effective screening tests available for the general population. As a result, diagnosis often occurs when the disease is already at an advanced stage, and hence the prognosis is poor. Abdominal pain/discomfort, abdominal distension, or gastrointestinal symptoms (eg, nausea, vomiting, and dyspepsia) are the most frequent presenting complaints but, occasionally, urinary symptoms or vaginal bleeding predominates. Physical examination usually detects ascites and pelvic mass. Imaging in the form of ultrasound and computed tomography scans confirm the findings in the abdomen and pelvis.

Risk factors for ovarian cancer include family history of ovarian/breast cancer, nulliparity, early menarche, late menopause, white race, and higher socioeconomic status. ${ }^{3}$ Protective factors include multiparity, use of the oral contraceptive pill, and tubal ligation. ${ }^{3,4}$ Although ovarian cancer still carries an extremely high case fatality ratio, the five-year relative survival in the US has increased from 37\% during 1975-1977 
to $45 \%$ during $1996-2002 .{ }^{1}$ Age is associated with significant prognostic implications in ovarian cancer. The five-year survival rates by age groups are $78.8 \%, 58.8 \%$, and $35.3 \%$ for very young ( $<30$ years), young $(30-60)$ and older $(>60)$ individuals, respectively. ${ }^{5}$

\section{Historic overview}

The National Cancer Institute (NCI) initiated a screening program to identify the biologic antitumor activity of thousands of naturally occurring plants in the 1960s, during which time a crude extract from the bark of the Pacific yew, Taxus brevifolia, showed activity against many tumor types. ${ }^{6}$ This is a slow-growing evergreen plant found in the old-growth forests of the Northwest Pacific. In 1971, investigators were able to isolate the active ingredient, paclitaxel, from the crude bark extract. ${ }^{6}$ In 1979 , Horwitz et al noted that the drug prevented cell division by promoting the assembly of microtubules without inhibiting their disassembly. ${ }^{7}$ In the initial phases, development was slow because paclitaxel did not appear to be more effective than other agents under development, and the procurement of this potentially scarce natural product in adequate quantities was deemed to be labor- and cost-intensive. However, paclitaxel displayed impressive activity in human tumor xenografts in nude mice and, by the mid-1980s, the NCI had initiated the clinical Phase I trials. ${ }^{8}$

\section{Structure}

The chemical name of paclitaxel is $5 \beta, 20$-epoxy-1,2 $\alpha, 4$, $7 \beta, 10 \beta, 13 \alpha$-hexahydroxytax-11-en-9-one4, 10-diacetate 2-benzoate 13-ester with (2R,3S)-N-benzoyl-3-phenylisoserine. The chemical formula of paclitaxel is $\mathrm{C}_{47} \mathrm{H}_{51} \mathrm{O}_{14}$, with a molecular weight of 853.9. It is highly lipophilic, insoluble in water, and melts at $217^{\circ} \mathrm{C}$. The structure of paclitaxel is in the form of a complex ring system that is linked to a four-member oxetan ring at positions $\mathrm{C} 4$ and $\mathrm{C} 5$ and to an ester side chain at $\mathrm{C} 13$. Some studies suggested that this side chain is responsible for the unique effect of paclitaxel on microtubules. ${ }^{9,10}$ In contrast, other studies showed that the side chain is not an absolute requirement for the biologic activity of paclitaxel, but lack of this may confer a structure that is not as active as paclitaxel. ${ }^{10,11}$

\section{Mechanism of action}

Microtubules play a key role in the initiation of DNA synthesis, mitosis, meiosis, motility, maintenance of cellular shape, and intracellular trafficking of macromolecules and organelles. Paclitaxel binds selectively and reversibly to the B subunit of tubulin, promoting tubulin polymerization and formation of stable microtubules even in the absence of the energy source, guanosine triphosphate. This effect leads to disruption of the equilibrium between the tubulin dimer-polymer in favor of polymer assembly. ${ }^{12,13}$ Paclitaxelinduced microtubules have unusual stability and resist depolymerization by calcium, cold temperature, and dilution. Cells exposed to the drug exhibit an accumulation of arrays of disorganized microtubules which cause profound cell cycle arrest at the G2/M phase and eventually result in cell death through an apoptotic pathway. ${ }^{12,13}$ Paclitaxel induces two distinct microtubular structures, ie, bundles and esters, which can be visualized by antitubulin antibody staining. Cells with esters produced by paclitaxel exposure are in mitosis and cells with paclitaxel-induced bundles are in the $\mathrm{G} 0 / \mathrm{G} 1, \mathrm{~S}$, and G2 phases. $^{9}$ At high concentration, paclitaxel increases polymer mass and induces microtubule bundle formation, while at low concentration the principal effect is suppression of microtubule dynamics without altering the polymer mass. ${ }^{14,15}$ At a molecular level, paclitaxel-induced apoptosis and drug resistance is thought to be mediated through alteration in function of p53, p21, Bcl-2, and Bcl-xL. ${ }^{16,17}$ Specifically, apoptosis mediated by caspase 3 and caspase 8 , hyperphosphorylation of $\mathrm{Bcl}-2$, and increased expression of Bax have been shown to be partly responsible for paclitaxel-associated cytotoxicity. ${ }^{18,19}$

\section{Pharmacokinetics}

Paclitaxel is a large complex structure, insoluble in water, and $>95 \%$ bound to protein. Therefore, paclitaxel uptake in the brain and testes is minimal, as demonstrated by radiolabeled drug studies. ${ }^{20}$ The bioavailability of paclitaxel is poor after oral administration due to enterocyte expression of P-glycoprotein (Pgp) and first-pass metabolism in the liver. Parental administration is therefore required. Early studies with prolonged infusions of paclitaxel were suggestive of linear pharmacokinetics. However, later studies showed that paclitaxel followed nonlinear pharmacokinetics due to saturable distribution, metabolism, and elimination. This is especially evident with shorter durations of infusion and/or high dose levels. ${ }^{21}$ At higher doses and administration rates, the plasma concentration of paclitaxel begins to exceed the metabolic capacity of the elimination pathways, thereby disproportionately increasing the area under the plasma-time curve. ${ }^{22,23}$ The clinical implication of nonlinearity is that dose escalation may result in a disproportionate increase in toxicity, whereas dose reduction may result in a disproportionate 
decrease in efficacy. The pharmaceutical vehicle used to dissolve paclitaxel, ie, Cremopher ${ }^{\circledR} \mathrm{EL}$, may affect the disposition of the drug and contribute to the reduction in plasma clearance observed at higher doses of paclitaxel. ${ }^{22}$ Pharmacodynamic analyses have strongly indicated that there is a relationship between percentage decrease in white blood cell count or absolute neutrophil count and the time for which plasma paclitaxel concentration is above the threshold level of $0.1 \mu \mathrm{mol} / \mathrm{L} .{ }^{22,23}$

\section{Metabolism}

The major pathway of elimination for paclitaxel is hepatic metabolism followed by biliary excretion. Renal clearance is minimal, with less than $15 \%$ of the drug excreted in urine. Paclitaxel is metabolized by CYP3A4 and CYP2C8; $6 \alpha$-hydroxy-paclitaxel is the major metabolite of paclitaxel that is formed by hydroxylation of $\mathrm{C} 6$ in the taxane ring by CYP2C8. This metabolite is approximately 30 -fold less active than the parent drug, as evident from the in vitro studies. Another minor metabolite of paclitaxel is 3'-para-hydroxypaclitaxel, which is produced by cytochrome P450 3A4. These more polar metabolites penetrate the cells poorly, hence they are either inactive or much less cytotoxic than the parent compound. . $22,24,25^{2}$

\section{Dosing strategy for paclitaxel}

Paclitaxel has been used in doses ranging from $60-250 \mathrm{mg} / \mathrm{m}^{2}$, over 1-96 hours and from 1-3 weekly intervals. However, no ideal dosing strategy for paclitaxel exists in ovarian cancer, even after almost two decades of its clinical use. Intense research efforts are underway to find the least toxic, least expensive, and most efficacious paclitaxel dosing strategy. Preclinical data suggested that prolonged exposure ( 96 hours) might have greater efficacy, but this was conclusively refuted by large prospective studies. ${ }^{26,27}$

Initial studies used arbitrarily selected 24-hour infusions to reduce the risk of hypersensitivity reactions, but the development of effective premedication regimens led to evaluation of a broad range of more convenient dosing schedules (Table 1). ${ }^{28}$

In a landmark Canadian-European trial designed to find the best clinically relevant dose of paclitaxel, 407 patients were randomized to receive 175 or $135 \mathrm{mg} / \mathrm{m}^{2}$ of paclitaxel over either 24 or three hours in a $2 \times 2$ design. Major

Table I Major studies with dose variations of paclitaxel in ovarian cancer (MOS and PFS in months unless otherwise indicated)

\begin{tabular}{|c|c|c|c|c|c|c|c|}
\hline Study & Agents/Schedule & Eligibility & $\mathbf{n}$ & $\begin{array}{l}\text { Response } \\
(\%)\end{array}$ & $\begin{array}{l}\text { MOS } \\
\text { (month) }\end{array}$ & $\begin{array}{l}\text { PFS } \\
\text { (month) }\end{array}$ & Comments \\
\hline $\begin{array}{l}\text { Spriggs et } \mathrm{al}^{27} \\
2007 \text { GOG I } 66\end{array}$ & $\begin{array}{l}\text { Paclitaxel } 135 \mathrm{mg} / \mathrm{m}^{2} / 24 \mathrm{~h}+ \\
\text { Cisplatin } 75 \mathrm{mg} / \mathrm{m}^{2} \text { vs } \\
\text { Paclitaxel } 120 \mathrm{mg} / \mathrm{m}^{2} / 96 \mathrm{~h}+ \\
\text { Cisplatin } 75 \mathrm{mg} / \mathrm{m}^{2}\end{array}$ & $\begin{array}{l}\text { Suboptimal } \\
\text { stage III } \\
\text { or IV }\end{array}$ & 280 & $\begin{array}{l}62 \\
70\end{array}$ & $\begin{array}{l}2.5 \mathrm{yr} \\
2.5 \mathrm{yr}\end{array}$ & $\begin{array}{l}\mathrm{I} y r \\
\mathrm{I} y r\end{array}$ & $\begin{array}{l}\text { Grade } 4 \text { neurotoxicity- } \\
79 \% \text { vs } 54 \% \\
\text { Grade } 3 \text { anemia - } 6 \% \\
\text { vs } 18 \% \text { Concluded that } \\
\text { longer infusions are not } \\
\text { better. }\end{array}$ \\
\hline $\begin{array}{l}\text { Omura et } \mathrm{al}^{31} \\
2003\end{array}$ & $\begin{array}{l}\text { Paclitaxel I } 35 \text { or } \\
175 \mathrm{mg} / \mathrm{m}^{2} / 24 \mathrm{~h} \text { vs } \\
\text { Paclitaxel } 250 \mathrm{mg} / \mathrm{m}^{2} / 24 \mathrm{~h}\end{array}$ & $\begin{array}{l}\text { Relapsed } \\
\text { ovarian } \\
\text { cancer }\end{array}$ & 330 & $\begin{array}{l}27 \\
36\end{array}$ & $\begin{array}{l}12.3 \\
13.1\end{array}$ & $\begin{array}{l}4.8 \\
5.5\end{array}$ & $\begin{array}{l}\text { Thrombocytopenia, } \\
\text { neuropathy, and myalgia- } \\
\text { greater with } 250 \mathrm{mg} / \mathrm{m}^{2} \\
\text { dose, which exhibited } \\
\text { a better response rate. } \\
\text { But no survival benefit to } \\
\text { justify paclitaxel } \\
250 \mathrm{mg} / \mathrm{m}^{2}+\text { filgrastim. }\end{array}$ \\
\hline Bolis et $\mathrm{al}^{30} 2004$ & $\begin{array}{l}\text { Paclitaxel } 175 \mathrm{mg} / \mathrm{m}^{2}+ \\
\text { Carboplatin AUC } 6 \text { vs } \\
\text { Paclitaxel } 225 \mathrm{mg} / \mathrm{m}^{2}+ \\
\text { Carboplatin AUC } 6\end{array}$ & IIB-IV & $\begin{array}{l}207 \\
219\end{array}$ & $\begin{array}{l}64 \\
56\end{array}$ & $\begin{array}{l}\text { 4-year } \\
\text { survival } \\
46 \% \\
47 \%\end{array}$ & $\begin{array}{l}4 \text { year PFS } \\
42 \% \\
39 \%\end{array}$ & $\begin{array}{l}\text { Concluded that } \\
175 \mathrm{mg} / \mathrm{m}^{2} \text { preferred } \\
\text { regimen. }\end{array}$ \\
\hline $\begin{array}{l}\text { Katsumata et } \mathrm{al}^{32} \\
2009\end{array}$ & $\begin{array}{l}\text { Paclitaxel } 80 \mathrm{mg} / \mathrm{m}^{2} / \mathrm{lh} / \mathrm{wk} \times \\
6 \text { cycles }+ \text { Carboplatin-AUC } \\
6 / 3 \text { wks vs Paclitaxel } \\
180 \mathrm{mg} / \mathrm{m}^{2} / 3 \mathrm{~h} / 3 \mathrm{wk} \times \\
6 \text { cycles }+ \text { Carboplatin AUC } \\
6 / 3 \text { wks }\end{array}$ & II-IV & 631 & $\begin{array}{l}56 \\
53\end{array}$ & $\begin{array}{l}3 \text {-year } \\
\text { survival } \\
72 \% \\
65 \%\end{array}$ & $\begin{array}{l}28 \\
17\end{array}$ & $\begin{array}{l}\text { Neutropenia } 92 \% \text { vs } 88 \% \text {. } \\
\text { Grade } 3 / 4 \text { anemia } 69 \% \text { vs } \\
44 \% \text {. Withdrawal because } \\
\text { of toxicity - higher in } \\
\text { dose-dense regimen } \\
\text { than in the conventional } \\
\text { regimen } \\
\text { ( } n=113 \text { vs } n=69)\end{array}$ \\
\hline
\end{tabular}

Abbreviations: AUC, area under curve; n, number; MOS, median overall survival; PFS, progression-free survival. 
endpoints were the frequency of significant hypersensitivity reactions and objective response rate. This trial showed equivalent efficacy of the three-hour versus 24-hour infusion schedules for paclitaxel in recurrent ovarian cancer, with reduced bone marrow toxicity and an increased incidence of neuropathy with the shorter infusions. Subsequently, the three-hour infusion schedule became the new standard due to its convenience and lesser cost compared with the other schedules. ${ }^{29}$ Furthermore, no clinically relevant advantage has been found with paclitaxel at a dose of $135 \mathrm{mg} / \mathrm{m}^{2}$ as compared with $225-250 \mathrm{mg} / \mathrm{m}^{2}$ in the setting of either upfront chemotherapy ${ }^{30}$ or relapsed disease. ${ }^{31}$ These observations paved the way for the concepts of weekly low-dose one-hour infusion and dose-dense paclitaxel. ${ }^{32}$ These strategies are believed to reduce the risk of serious toxicity and alopecia markedly, with maintenance of clinical efficacy. ${ }^{33}$

Katsumata et al recently reported a Phase III study of dose-dense paclitaxel in front-line ovarian cancer comparing standard chemotherapy including paclitaxel $180 \mathrm{mg} / \mathrm{m}^{2}$ over three hours every three weeks with a dose-dense regimen which included paclitaxel $80 \mathrm{mg} / \mathrm{m}^{2}$ over one hour every week in a three-week cycle. There was prolongation of progression-free survival (PFS), as well as median survival, in the dose-dense arm at the cost of a significant increase in toxicity (Table 1). ${ }^{32}$ This study suggests that dose-dense paclitaxel may be of clinical benefit, but that toxicities must be mitigated before it can be adopted widely. ${ }^{34}$ Others have reported different doses on a weekly schedule as well. ${ }^{35-37}$ Suffice it to say that a weekly dosing strategy for paclitaxel in ovarian cancer remains under investigation.

\section{Drug interactions}

Because paclitaxel has saturable distribution and elimination at the currently used dosage, small changes in its pharmacokinetics could potentially cause serious effects, especially if the toxic effect is enhanced or, conversely, if the cytotoxic antitumor effect is diminished by drug interaction.

\section{Interaction with other cytotoxic drugs Cisplatin}

The sequence of cisplatin $75 \mathrm{mg} / \mathrm{m}^{2}$ followed by paclitaxel infusion at $135 \mathrm{mg} / \mathrm{m}^{2}$ over 24 hours is associated with more profound neutropenia and less in vitro antitumor activity. ${ }^{38}$ The hepatic clearance of paclitaxel may be decreased by $33 \%$ when it is preceded by cisplatin. ${ }^{38}$ The precise mechanism is unclear, but this could be caused by cisplatin-induced modulation of cytochrome P450 metabolism or damage to the kinestin heavy chain gene which plays a role in the cytotoxicity of many natural-based antitumor drugs. ${ }^{39}$ Sequence dependence is unlikely to be clinically relevant with shorter paclitaxel infusion schedules. Moreover carboplatin, the more commonly used platinum agent, does not appear to modulate cytochrome $\mathrm{P} 450$ systems or the pharmacokinetics of paclitaxel..$^{40-42}$

\section{Doxorubicin}

Paclitaxel exhibits a sequence- and schedule-dependent interaction with doxorubicin. ${ }^{43}$ It increases the area under the curve (AUC) of doxorubicin by 30\% when given before or immediately after doxorubicin and consequently increases the incidence of doxorubicin-induced cardiotoxicity and myelosuppression, however, neither sequence of drug infusion significantly influenced the AUC of paclitaxel. ${ }^{43,44}$ Based on these observations, it was recommended to restrict the cumulative dose of doxorubicin to $360 \mathrm{mg} / \mathrm{m}^{2}$, to administer doxorubicin 24 hours before paclitaxel, ${ }^{43}$ and to use dexrazoxane with the combination as well. ${ }^{44}$

\section{Etoposide}

Paclitaxel and etoposide exhibit schedule-dependent interaction and optimal synergism with sequential 24-hour use, without the impact of an intervening drug-free period. In contrast, less than additive inhibitory cytotoxicity is observed with concurrent administration of these agents in in vitro experiments. ${ }^{45}$ Other studies have reported independent antagonism with these two agents. ${ }^{46}$ However, the clinical relevance of these observations remains to be elucidated.

\section{Topotecan}

The sequential combination of paclitaxel and topotecan resulted in severe dose-limiting myelosuppression, although there is no established pharmacodynamic or pharmacokinetic interaction between the two agents to explain this observation. $^{43}$

\section{Trastuzumab}

In breast cancer patients, the incidence of congestive heart failure has been higher with the trastuzumabpaclitaxel combination than with paclitaxel alone. Data are preliminary and the reason for this association is unknown. ${ }^{47}$ 


\section{Interaction with noncytotoxic drugs}

The maximum tolerated dose of paclitaxel in cancer patients receiving anticonvulsant therapy, such as phenytoin and phenobarbital, is higher compared with those on no anticonvulsant therapy $\left(200 \mathrm{mg} / \mathrm{m}^{2}\right.$ versus $\left.140 \mathrm{mg} / \mathrm{m}^{2}\right) .^{48}$ This may be due to enhanced hepatic clearance which could result in reduction of the cytotoxic and antitumor effects of paclitaxel ${ }^{48}$ Explanation involves induction of cytochrome P450 mixed-function oxidases by the anticonvulsants. ${ }^{49}$

\section{Paclitaxel in early ovarian cancer}

The treatment strategy for early-stage ovarian cancer has evolved differently compared with that of late-stage disease, which is reflective of the higher relative prevalence and mortality of the latter compared with the former. Currently, the suggested treatment for early-stage ovarian cancer (FIGO I and II) in the US is optimal surgical staging followed by either chemotherapy or expectant management, depending on the stage and grade of the disease..$^{50}$ Patients with Stage IA or IB disease with Grade I and II tumor have a greater than $90 \%$ cure rate, and require no further postoperative treatment, while patients with a Stage I Grade 3 lesion or Stage II disease have a recurrence rate of approximately $25 \%-40 \%$ and will need additional postoperative chemotherapy. ${ }^{50}$ The duration of chemotherapy has been addressed by GOG protocol 157, where the investigators enrolled 427 stage I and II high-risk patients and compared three versus six cycles of paclitaxel at $175 \mathrm{mg} / \mathrm{m}^{2}$ for three hours plus carboplatin-AUC $7.5 .^{51}$ Both arms in the study had similar death rates, and the estimated probability of recurrence within five years was $20.1 \%$ (six cycles) versus $25.4 \%$ (three cycles), respectively. The respective Grade 3 or 4 neurotoxicity was $11 \%$ versus $2 \%$. Six cycles also caused significantly more severe anemia and granulocytopenia. In other words, this study showed a minimal reduction in risk of recurrence, with a significant increase in toxicity due to the six cycles, and thus it is advocated for only three cycles of combination therapy in this setting. Several limitations of the study have been highlighted, and some continue to argue for the use of more chemotherapy in early-stage ovarian cancer, especially if the initial three cycles are tolerated without significant toxicity in patients with high-risk features. ${ }^{52} \mathrm{Also}$, a subsequent idea originating from this study was the GOG 175 protocol where the same patient population with high-risk, early-stage ovarian cancer is being randomized to either three cycles of carboplatin(AUC 6) with paclitaxel $175 \mathrm{mg} / \mathrm{m}^{2}$ or three cycles of the same regimen followed by weekly paclitaxel $40 \mathrm{mg} / \mathrm{m}^{2}$ for 24 weeks. Results of this study are pending.

\section{Paclitaxel in advanced ovarian cancer}

Encouraged by successful completion of several Phase I trials safely administering paclitaxel and the subsequent response in other tumor types, several groups started using paclitaxel for ovarian cancer in Phase II trials. ${ }^{53-55}$ In the initial studies, an extremely high rate of hypersensitivity reactions of up to $30 \%$ was noted. To ameliorate this, longer infusion (24-96 hours) $)^{53,56}$ and pretreatment with antihistamine agents and steroids became necessary. These strategies, when used in combination, reduced the risk of severe hypersensitivity reactions to $5 \%$ or less, but marked the emergence of doselimiting neutropenia. It is noteworthy that some of the initial trials of paclitaxel included both platinum-sensitive as well as platinum-refractory patients, with response rates ranging from $20 \%$ to $37 \% .57,58$

Due to the excellent response rates seen in these studies, the next logical step was to combine paclitaxel with platinum compounds, which are arguably the agents with the best activity in ovarian cancer. Validating this notion was a Phase I study ${ }^{38}$ showing that paclitaxel and cisplatin could be given safely in combination, with paclitaxel administered first as a 24-hour infusion.

Subsequently, four major trials have been reported which compared platinum-paclitaxel doublets with other agents (Table 2). The first two of these (GOG $111^{59}$ and OV- $10^{60}$ ) helped to establish platinum-paclitaxel as front-line therapy in ovarian cancer, whereas the subsequent two trials (GOG $132^{61}$ and ICON ${ }^{62}$ ) have questioned whether the addition of paclitaxel to platinum provides any additional benefit.

In GOG 111, a cyclophosphamide-cisplatin doublet was compared with paclitaxel-cisplatin in patients with stages III and IV ovarian cancer. The authors reported a response rate of $60 \%$ versus $73 \%$, a PFS of 13 versus 18 months, and median survival of 24 versus 38 months, respectively, favoring the paclitaxel-cisplatin doublet compared with the cyclophosphamide-cisplatin doublet. On the other hand, OV-10 showed an overall survival of 26 versus 36 months and a PFS of 12 versus 16 months $(P<0.05)$, both favoring the paclitaxel-cisplatin doublet (Table 2).

In GOG 132, 648 suboptimally debulked stage III and IV epithelial ovarian cancer patients were randomized to receive cisplatin or paclitaxel or the combination of paclitaxel-cisplatin. This trial concluded that cisplatin alone or in combination yielded superior response rates and a PFS relative to paclitaxel. However, the OS (overall survival) was similar in all three arms, and the combination therapy had a better toxicity profile. Therefore, the authors argued 
Table 2 Phase III trials of paclitaxel and platinum compounds in front-line chemotherapy for advanced ovarian cancer

\begin{tabular}{|c|c|c|c|c|c|c|c|}
\hline Study & Agents/Schedule & Eligibility (Stage) & $\mathbf{n}$ & $\begin{array}{l}\text { Response } \\
\text { (\%) }\end{array}$ & $\begin{array}{l}\text { MOS } \\
\text { (months) }\end{array}$ & $\begin{array}{l}\text { PFS } \\
\text { (months) }\end{array}$ & Comments \\
\hline McGuire et al ${ }^{59}$ & Paclitaxel $135 \mathrm{mg} / \mathrm{m}^{2} / 24 \mathrm{~h}+$ & Suboptimal III, IV & 386 & 73 vs 60 & 38 & 18 & \\
\hline 1996 & Cisplatin $75 \mathrm{mg} / \mathrm{m}^{2} ;$ six cycles vs & & & & 24 & 13 & \\
\hline GOG-III & $\begin{array}{l}\text { Cyclophosphamide } 750 \mathrm{mg} / \mathrm{m}^{2}+ \\
\text { Cisplatin } 75 \mathrm{mg} / \mathrm{m}^{2} ; \text { six cycles }\end{array}$ & & & & & & \\
\hline Piccart et al ${ }^{10}$ & Paclitaxel $135 \mathrm{mg} / \mathrm{m}^{2} / 3 \mathrm{~h}+$ & Optimal or & 680 & 59 vs 45 & 36 & 16 & Neurotoxicity \\
\hline 2000 & Cisplatin $75 \mathrm{mg} / \mathrm{m}^{2}$ vs & suboptimal IIB-IV & & & 26 & 12 & $19 \%$ vs $1 \%$ \\
\hline OV-10 & $\begin{array}{l}\text { Cyclophosphamide } 750 \mathrm{mg} / \mathrm{m}^{2}+ \\
\text { Cisplatin } 75 \mathrm{mg} / \mathrm{m}^{2}\end{array}$ & & & & & & \\
\hline Muggia et $a^{61}$ & Paclitaxel $135 \mathrm{mg} / \mathrm{m}^{2} / 24 \mathrm{~h}+$ & Suboptimal III, & 614 & 67 vs 42 & 26 & 14 & \\
\hline 2000 & Cisplatin $75 \mathrm{mg} / \mathrm{m}^{2}$ vs paclitaxel & Any IV & & vs 67 & 26 & 11 & \\
\hline GOGI32 & $\begin{array}{l}200 \mathrm{mg} / \mathrm{m}^{2} / 24 \mathrm{~h} \text { vs cisplatin } \\
100 \mathrm{mg} / \mathrm{m}^{2}\end{array}$ & & & & 30 & 16 & \\
\hline ICON362 2002 & $\begin{array}{l}\text { Paclitaxel } 175 \mathrm{mg} / \mathrm{m}^{2} / 3 \mathrm{~h}+ \\
\text { Carboplatin AUC } 6 \text { Vs CAP or } \\
\text { Carboplatin }\end{array}$ & $\mathrm{I}-\mathrm{IV}$ & 2075 & NA & $\begin{array}{l}36 \\
35\end{array}$ & $\begin{array}{l}17 \\
16\end{array}$ & \\
\hline
\end{tabular}

Abbreviations: AUC, area under curve; n, number; CAP, cyclophosphamide-doxorubicin-cisplatin combination; MOS, median overall survival (in months unless otherwise indicated); PFS, progression free survival (in months unless otherwise indicated).

that the cisplatin-paclitaxel combination should remain the preferred initial treatment option. Perhaps the best rationale for lack of observed superior response with the platinumpaclitaxel doublet was the inclusion of a suboptimal control arm due to more than half of the patients in the single-agent arms crossing over to the other agents subsequently on a nonprotocol basis. ${ }^{61}$

The results of ICON3 were reported in 2002 in which paclitaxel-carboplatin versus carboplatin or cyclophosphamide-doxorubicin-cisplatin (CAP) were compared. No difference was found in OS between the paclitaxel-carboplatin and control groups. The trial concluded that single-agent carboplatin and CAP are as effective as the paclitaxel-carboplatin doublet. Also, the favorable toxicity profile of single-agent carboplatin suggested that this drug may be a reasonable option as first-line chemotherapy for ovarian cancer. ${ }^{62}$ This trial called into question the additional benefit offered by paclitaxel over the platinum compounds, but was not successful in changing the practice on a large scale in patients due to several limitations which are analyzed by Sandercock et al in detail. ${ }^{63}$

Several theoretical arguments support the concurrent use of paclitaxel with platinum in ovarian cancer. Firstly, addition of a second agent may be useful in reducing the possibility of development of resistant clones. Secondly, a greater cell kill might be achieved at the start of the treatment, which may mean a higher proportion of patients becoming tumor-free at induction chemotherapy. Thirdly, the dual agent approach may help to lower the doses, and hence the toxicity of each of the single agents involved, and still preserve acceptable efficacy. Support for these notions comes from a metaanalysis in which the platinum-paclitaxel doublet still had an edge over the other agents. ${ }^{63}$ Consequently, platinum and paclitaxel remain the preferred front-line chemotherapy for ovarian cancer in the US.

Due to the significant side effects of cisplatin, including nausea/vomiting, neurotoxicity, and nephrotoxicity, several trials have looked at substituting cisplatin with carboplatin, a better tolerated platinum compound. A study by Neijt et al ${ }^{64}$ compared paclitaxel at $175 \mathrm{mg} / \mathrm{m}^{2}$ for three hours with cisplatin or carboplatin, and a study by du Bois et $\mathrm{al}^{65}$ compared paclitaxel at $185 \mathrm{mg} / \mathrm{m}^{2}$ with either cisplatin or carboplatin as front-line chemotherapy in ovarian cancer. Both these studies showed similar response rates, PFS, and OS in the cisplatin and carboplatin arms. Similar findings were reported by Ozols et al in a GOG study. ${ }^{66}$ As expected, more gastrointestinal and neurologic toxicity was found in patients receiving cisplatin and more myelosuppression in patients randomized to carboplatin, but overall, the latter resulted in lesser toxicity, more convenient dosing, and no inferiority when compared with the former agent. Hence, intravenous (IV) carboplatin has replaced IV cisplatin in clinical practice around the world.

\section{Paclitaxel in recurrent ovarian cancer}

Approximately two-thirds of patients will respond to frontline chemotherapy in ovarian cancer, but the majority of these women will have disease recurrence. Cure is rare and, therefore, the goals of treatment in recurrent ovarian cancer 
Table 3 Major trials employing a third agent with the paclitaxel-carboplatin doublet

\begin{tabular}{|c|c|c|c|c|}
\hline Study & Schedule/Agents & $\mathbf{n}$ & PFS/MOS & Comments \\
\hline du Bois et al ${ }^{102}$ & $\begin{array}{l}\text { TEC arm } \\
\text { Paclitaxel } 175 \mathrm{mg} / \mathrm{m}^{2}+\text { carboplatin } \\
\text { AUC- } 5+\text { epirubicin } 60 \mathrm{mg} / \mathrm{m}^{2} \\
\text { Every } 3 \text { wks } \times 6 \text { cycles vs } \\
\text { Paclitaxel } 175 \mathrm{mg} / \mathrm{m}^{2}+\text { carboplatin AUC- } 5 \\
\text { Every } 3 \text { wks } \times 6 \text { cycles }\end{array}$ & 1282 & $|8 / 4|$ & $\begin{array}{l}\text { Grade 3-4 hematological toxicities and } \\
\text { grade 3-4 febrile neutropenia-more } \\
\text { frequent in the first group. Nausea, } \\
\text { vomiting, stomatitis/mucositis and } \\
\text { infections-significantly less frequent in } \\
\text { the second group. Inferior quality of life in } \\
\text { TEC arm }\end{array}$ \\
\hline Scarfone et al ${ }^{103}$ & $\begin{array}{l}\text { Paclitaxel } 175 \mathrm{mg} / \mathrm{m}^{2} \text { DI } \\
\text { Carboplatin AUC-5 DI } \\
\text { Topotecan I mg/m² DI-3 } \\
\text { Every } 3 \text { weeks for } 6 \text { cycles vs } \\
\text { Paclitaxel } 175 \mathrm{mg} / \mathrm{m}^{2} \text { DI } \\
\text { Carboplatin AUC-5 DI } \\
\text { Every } 3 \text { weeks for } 6 \text { cycles }\end{array}$ & 326 & $\begin{array}{l}\text { Median PFS } \\
72 \text { vs } 70 \text { weeks }\end{array}$ & $\begin{array}{l}\text { Grade } 3 / 4 \text { neutropenia } 40 \% \text { vs } 24 \% \text {. } \\
\text { Alopecia } 72 \% \text { vs } 78.2 \% \text { and nausea/ } \\
\text { vomiting } 51 \% \text { vs } 44 \%\end{array}$ \\
\hline $\begin{array}{l}\text { GOGI82-ICON5 } 104 \\
\text { Phase III }\end{array}$ & $\begin{array}{l}\text { ARM I Control } \\
\text { Paclitaxel I75 mg/m² DI } \\
\text { Carboplatin AUC } 6 \text { DI } \\
\text { Every } 3 \text { wks for } 8 \text { cycles } \\
\text { ARM } 2 \text { Gemcitabine triplet } \\
\text { Paclitaxel I75 mg/m² DI } \\
\text { Carboplatin AUC } 5 \text { DI } \\
\text { Gemcitabine } 800 \mathrm{mg} / \mathrm{m}^{2} \text { D I,8 } \\
\text { Every } 3 \text { wks for } 8 \text { cycles. } \\
\text { ARM } 3 \text { Doxil triplet } \\
\text { Paclitaxel I75 mg/m² DI } \\
\text { Carboplatin AUC } 5 \text { DI } \\
\text { Doxil } 30 \mathrm{mg} / \mathrm{m}^{2} \text { (cycle I, 3, 5, 7) } \\
\text { Every } 3 \text { wks for } 8 \text { cycles. } \\
\text { ARM } 4 \text { Topotecan doublet } \\
\text { Carboplatin AUC } 5 \text { D3 (Cycle I-4) } \\
\text { Topotecan I.25 mg/m²/day DI-3 (cycle I-4) } \\
\text { Paclitaxel I75 mg/m² in } 3 \text { h DI (cycle 5-8) } \\
\text { Carboplatin AUC } 6 \text { DI (cycle 5-8) } \\
\text { ARM } 5 \text { Gemcitabine doublet } \\
\text { Carboplatin AUC } 6 \text { D8 (cycle I-4) } \\
\text { Gemcitabine I000 mg/m²/day DI-8 (cycle I-4) } \\
\text { Paclitaxel I } 75 \mathrm{mg} / \mathrm{m}^{2} \text { in } 3 \text { h DI (cycle 5-8) } \\
\text { Carboplatin AUC } 6 \text { DI (cycle 5-8) }\end{array}$ & 4412 & $\begin{array}{l}\text { No significant } \\
\text { difference in the } \\
\text { PFS and OS }\end{array}$ & $\begin{array}{l}\text { Increased hematologic toxicity with triplet } \\
\text { regimens. Increased thrombocytopenia } \\
\text { with gemcitabine. Neuropathy decreased } \\
\text { in doublet group which included only four } \\
\text { cycles of Paclitaxel. }\end{array}$ \\
\hline $\begin{array}{l}\text { Penson et al }{ }^{105} \\
\text { Phase II }\end{array}$ & $\begin{array}{l}\text { Paclitaxel } 175 \mathrm{mg} / \mathrm{m}^{2} \text { in } 3 \mathrm{~h} \text {-cycle I-6 } \\
\text { Carboplatin AUC } 6 \text { cycle I-6 } \\
\text { Bevacizumab } 15 \mathrm{mg} / \mathrm{kg} \text { in cycle } 2-6 \text { then } \\
\text { continued for I year }\end{array}$ & 62 & $\begin{array}{l}\text { PFS at } 36 \text { months } \\
58 \% \text {. Radiographic } \\
\text { response rate } 75 \%\end{array}$ & $\begin{array}{l}2 \text { cases of pulmonary embolism and } 2 \text { of } \\
\mathrm{Gl} \text { perforations. }\end{array}$ \\
\hline $\begin{array}{l}\text { Micha et al }{ }^{106} \\
\text { Phase II }\end{array}$ & $\begin{array}{l}\text { Paclitaxel } 175 \mathrm{mg} / \mathrm{m}^{2} \text { in } 3 \mathrm{~h} \text {-cycle I-6 } \\
\text { Carboplatin AUC } 6 \text { cycle I-6 } \\
\text { Bevacizumab } 15 \mathrm{mg} / \mathrm{kg} \text { cycle } 2-6\end{array}$ & 20 & $80 \%$ Overall response & $\begin{array}{l}\text { Grade } 3 \text { and } 4 \text { neutropenia } 23 \% \text { and } 25 \% \\
\text { cycles. No Gl perforation, } 2 \text { cases of } \\
\text { grade } 3 \text { hypertension and } 2 \text { cases of DVT }\end{array}$ \\
\hline
\end{tabular}

Abbreviations: AUC, area under curve; DVT, deep vein thrombosis; MOS, median overall survival (in months unless otherwise indicated); $n$, number; PFS, progression-free survival (in months unless otherwise indicated); TEC, paclitaxel-etoposide-cyclophosphamide combination; GI, gastrointestinal.

are maintaining an acceptable quality of life, control of symptoms, and prolonging survival, if possible. ${ }^{67}$

It has been established that a longer time interval to relapse after the initial platinum-based therapy (the platinum-free interval) was associated with a higher response rate to retreatment with platinum as well as other drugs. ${ }^{68,69}$ Accordingly, patients who relapsed within six months of completing initial platinum-based therapy were classified as platinum-resistant whereas those who relapsed after six months were considered to be platinum-sensitive.

In addition to platinum and taxanes, several agents have shown activity in relapsed ovarian cancer, including bevacizumab, ${ }^{70}$ altretamine (hexamethylmelamine), ${ }^{71}$ liposomal doxorubicin, ${ }^{72,73}$ topotecan, ${ }^{74,75}$ gemcitabine, ${ }^{76-78}$ oral etoposide, ${ }^{79,80}$ ifosfamide, ${ }^{81}$ navelbine, capecitabine, tamoxifen, and pemetrexed. Research in this area continues to grow 
as more anticancer agents are discovered. Whereas the best response rates in platinum-resistant patients have been in the $10 \%-20 \%$ range, response rates for platinum-sensitive disease have generally been much higher.

\section{Paclitaxel in platinum-sensitive recurrence}

Studies in platinum-sensitive patients can be classified into one of three groups, ie, non-platinum single-agent treatment, non-platinum combinations, and platinum-containing combinations (see Table 4A). In 1997 ten Bokkel Huinink et al published a trial ${ }^{82}$ comparing topotecan with paclitaxel and did not find significant differences between the two groups for response rates or survival. ${ }^{83}$ However, paclitaxel was much less toxic to bone marrow than topotecan. The European Organisation for Research and Treatment of Cancer (EORTC) randomized 86 women to either single-agent paclitaxel or oxaliplatin. Response in the 63 platinum-resistant group was $16 \%$ versus $6 \%$ in the paclitaxel versus oxaliplatin arms, respectively, and for the platinum-sensitive group was $20 \%$ versus $38 \%$, respectively. ${ }^{84}$
In one Phase II study of a platinum-free interval (PFI) $>12$ months, paclitaxel $175 \mathrm{mg} / \mathrm{m}^{2}$ IV over three hours was compared with the CAP regimen. Although the overall response rates were similar, CAP was associated with significant increases in response duration (16 versus 9 months) and median survival (35 versus 26 months). The authors concluded that single-agent paclitaxel may not be as active as platinum-based chemotherapy in recurrent ovarian cancer. ${ }^{85}$

A body of evidence supports the use of a platinumpaclitaxel doublet in women with platinum-sensitive relapse. Although the best response is seen in patients with a PFI of $>24$ months, response rates as high as $60 \%$ and a complete response rate of up to $25 \%$ may be achieved. A retrospective study of patients treated with paclitaxel-carboplatin reported a response rate of $84 \%$. The PFS and OS were 9.7 and 13.1 months, respectively. ${ }^{86}$ In a Phase II study, the Spanish Ovarian Cancer Research Group (GEICO) compared carboplatin with the paclitaxelcarboplatin doublet. With no significant difference in Grade 3-4 hematologic toxicity, the response rate favored

Table 4A Paclitaxel in platinum-sensitive recurrent ovarian cancer

\begin{tabular}{|c|c|c|c|c|}
\hline Study & Agent/Schedule & $\mathbf{n}$ & Response (\%) & Comments \\
\hline $\begin{array}{l}\text { ten Bokkel } \\
\text { Huinink et al }\end{array}$ & $\begin{array}{l}\text { Topotecan }\left(1.5 \mathrm{mg} / \mathrm{m}^{2}\right) \text { as a } 30 \text {-minute } \\
\text { infusion daily for } 5 \text { days q2 I days vs } \\
\text { paclitaxel }\left(175 \mathrm{mg} / \mathrm{m}^{2}\right) / 3 \mathrm{~h} \text { q2 I days }\end{array}$ & 226 & $\begin{array}{l}20.5 \text { vs } 13.2 \\
(P=0.138)\end{array}$ & $\begin{array}{l}\text { Neutropenia was significantly more } \\
\text { frequent on the topotecan arm } \\
79 \% \text { vs paclitaxel arm } 23 \% \\
(P<0.01) . \text { Median survival } 63 \text { vs } \\
53 \text { weeks }\end{array}$ \\
\hline Piccart et $\mathrm{al}^{84}$ & $\begin{array}{l}\text { Paclitaxel at } 175 \mathrm{mg} / \mathrm{m}^{2} / 3 \mathrm{~h} \\
\text { q3 weeks, vs oxaliplatin at } 130 \mathrm{mg} / \mathrm{m}^{2} / \\
2 \mathrm{~h} \text { q3 weeks }\end{array}$ & 86 & $\begin{array}{l}20 \text { vs } 38 \text { for sensitive disease } \\
16 \text { vs } 6 \text { for resistant disease }\end{array}$ & $\begin{array}{l}\text { Neutropenia } 22 \% \text { vs none } \\
\text { Neurotoxicity } 7 \% \text { vs } 9 \%\end{array}$ \\
\hline Cantu et $\mathrm{al}^{85}$ & $\begin{array}{l}\text { Paclitaxel } 175 \mathrm{mg} / \mathrm{m}^{2} \mathrm{IV} / 3 \mathrm{~h} \\
\text { q3 weeks vs cyclophosphamide, } \\
\text { Doxorubicin, and cisplatin (CAP) }\end{array}$ & 97 & 45 vs 55 & $\begin{array}{l}\text { Leukopenia } 4 \% \text { vs } 34 \% \text {, neutropenia } \\
\text { I3\% vs } 36 \% \text { MOS } 25.8 \text { vs } 34.7 \text { months } \\
(P<0.043)\end{array}$ \\
\hline Buda et $a^{89}$ & $\begin{array}{l}\text { Epidoxorubicin + paclitaxel I } 75 / 3 \mathrm{~h} \text {, } \\
\text { q2I days for } 4-6 \text { cycles vs paclitaxel } \\
175 \mathrm{mg} / \mathrm{m}^{2} / 3 \mathrm{~h} \text {, q2 I days for } \\
4-6 \text { cycles }\end{array}$ & 212 & 37 vs 47 & Neutropenia: $37 \%$ vs $18 \%$ \\
\hline $\begin{array}{l}\text { Pujade-Lauraine et al } \\
2009 \text { ASCO CALYPSO } \\
\text { study }\end{array}$ & $\begin{array}{l}\text { Carboplatin with PLD vs carboplatin } \\
\text { with paclitaxel }\end{array}$ & 976 & NA & $\begin{array}{l}\text { PFS I I vs } 9 \text { months, } P<0.05 \text { PLD } \\
\text { arm had fewer infusion reactions, less } \\
\text { alopecia and less chronic neurotoxicity }\end{array}$ \\
\hline Gronlund et al ${ }^{86}$ & $\begin{array}{l}\text { Paclitaxel }\left(175 \mathrm{mg} / \mathrm{m}^{2}\right) / 3 \mathrm{~h} \text { followed by } \\
\text { carboplatin AUC 5, q3 weeks }\end{array}$ & 241 & 84 & Retrospective MOS I3.I; PFS 9.7 \\
\hline Gonzalez-Martin et $\mathrm{al}^{87}$ & $\begin{array}{l}\text { Carboplatin AUC } 5 \text { vs paclitaxel } \\
175 \mathrm{mg} / \mathrm{m}^{2}+\text { carboplatin AUC } 5\end{array}$ & 81 & 50 vs 76 & $\begin{array}{l}\text { No differences in hematological } \\
\text { toxicity. Mucositis, myalgia/arthralgia } \\
\text { and peripheral neuropathy were more } \\
\text { frequent in combination therapy. }\end{array}$ \\
\hline Parmar et $\mathrm{al}^{88}$ & $\begin{array}{l}\text { Paclitaxel } 175-185 \mathrm{mg} / \mathrm{m}^{2}+\text { cisplatin } 50 \\
\mathrm{mg} / \mathrm{m}^{2} / \text { carboplatin AUC } 5-6 \text { vs cisplatin } \\
75 \mathrm{mg} / \mathrm{m}^{2} / \text { carboplatin } \\
\text { AUC } 5-6\end{array}$ & 802 & 78 vs $69 P=0.06$ & MOS 29 vs 24 \\
\hline
\end{tabular}

Abbreviations: AUC, area under curve; CAP, cyclophosphamide-doxorubicin-cisplatin combination; IV, intravenous; MOS, median overall survival (in months unless otherwise indicated); n, number; NA, not applicable; PFS, progression free survival (in months unless otherwise indicated); PLD, pegylated liposomal doxorubicin. 
the platinum-paclitaxel doublet ( $75.6 \%$ and $50 \%) .{ }^{87}$ The best evidence yet in favor of using a platinum-paclitaxel doublet for platinum-sensitive relapse comes from the ICON4 trial where 802 patients with platinum-sensitive relapse were randomized to paclitaxel-platinum or singleagent platinum. The trial showed a two-year survival rate of $57 \%$ versus $50 \%$, favoring the combination (hazard ratio $0.82 ; 95 \%$ confidence interval $[\mathrm{CI}] 0.69-0.97, P=0.02$ ). There was a higher incidence of Grade 2-4 neurologic effects ( $20 \%$ versus $1 \%$ ), alopecia ( $86 \%$ versus $25 \%$ ), and a lower rate of myelosuppression in the paclitaxel-treated patients. $^{88}$

An Italian trial compared an epidoxorubicin-paclitaxel doublet with paclitaxel alone and favored the latter based on a better response rate. ${ }^{89}$ More recently, the CALYPSO study compared carboplatin plus either pegylated liposomal doxorubicin (PLD) or paclitaxel in 976 women with relapsed platinum-sensitive disease. In preliminary findings presented at the 2009 ASCO meeting, ${ }^{90}$ PLD-carboplatin was not inferior to paclitaxel-carboplatin, was associated with a significant prolongation in PFS (11.3 versus 9.4 months), and was less toxic. The investigators concluded that PLDcarboplatin could be considered a valid alternative to carboplatin-paclitaxel for treatment of platinum-sensitive disease.

\section{Paclitaxel in platinum-resistant disease}

Single-agent taxanes have produced response rates in the $20 \%$ range for platinum-resistant disease in Phase II and III studies $^{57,58,91,92}$ (see Table 4B). There is no agreement on the optimal schedule and dose of paclitaxel in recurrent ovarian cancer. In one trial, doses of 135 to $175 \mathrm{mg} / \mathrm{m}^{2}$ every three weeks, either as a three-hour or 24-hour infusion, showed similar response rates. Three-hour infusions were associated with more neurotoxicity but less myelosuppression. ${ }^{29}$ Others have used higher doses of paclitaxel in the Phase III setting ( 250 versus $175 \mathrm{mg} / \mathrm{m}^{2}$ per dose) with hematopoietic growth factor support and reported higher response rates, and significantly more thrombocytopenia, neuropathy, and myalgia, but no improvement in survival with the higher dosage $(P<0.05) \cdot{ }^{31}$ Thigpen et al used longer infusions of paclitaxel at $170 \mathrm{mg} / \mathrm{m}^{2}$ IV once over 24 hours every three weeks, and reported Grade 4 neutropenia in $73 \% .{ }^{57}$ Weekly paclitaxel may maintain antitumor efficacy while minimizing toxicity, especially myelosuppression. This concept has been tested by several studies in the setting of relapsed ovarian cancer. Markman et al reported two Phase II studies of weekly paclitaxel with response rates of $20 \%-25 \% .{ }^{93,94}$ In the first study, five of 53 patients discontinued therapy because of toxicity (four due to peripheral

Table 4B Paclitaxel in platinum-resistant recurrent ovarian cancer

\begin{tabular}{|c|c|c|c|c|}
\hline Study & Agent/Schedule & $\mathbf{n}$ & Response (\%) & Comments \\
\hline McGuire et $\mathrm{al}^{91}$ & $\begin{array}{l}\text { Paclitaxel I } 10 \text { to } 250 \mathrm{mg} / \mathrm{m}^{2} / 24 \mathrm{~h} \\
\text { q22 days }\end{array}$ & $\begin{array}{l}40 \text { total } \\
25 \text { resistant }\end{array}$ & 24 & $\begin{array}{l}\text { Myelosupression dose limiting } \\
\text { toxicity; } 2 \text { fatal cases of sepsis. }\end{array}$ \\
\hline Thigpen et $\mathrm{al}^{57}$ & Paclitaxel $170 \mathrm{mg} / \mathrm{m}^{2} / \mathrm{IV} / 24 \mathrm{~h} / \mathrm{q} 3$ weeks & $\begin{array}{l}43 \text { total } \\
27 \text { resistant }\end{array}$ & 33 & Neutropenia $73 \%$ \\
\hline Trimble et al ${ }^{143}$ & Paclitaxel I $35 \mathrm{mg} / \mathrm{m}^{2} / \mathrm{IV} / 24 \mathrm{~h} / \mathrm{q} 3$ weeks & 652 & 22 & $\begin{array}{l}\text { Leucopenia } 78 \% \text { fever } 33 \% \text {, } \\
\text { infection } 12 \% \text {. }\end{array}$ \\
\hline Markman et al ${ }^{93}$ & Weekly paclitaxel 80 mg/m² & 53 & 25 & $\begin{array}{l}5 \text { patients dropped due to } \\
\text { toxicity, } 4 \text { due to peripheral } \\
\text { neuropathy, and I because of } \\
\text { painful fingernail beds }\end{array}$ \\
\hline Markman et al ${ }^{94}$ & Weekly paclitaxel 80 mg/m² & 48 & 21 & $\begin{array}{l}\text { Grade } 3 \text { neuropathy: } 4 \% \text {; grade } \\
3 \text { fatigue: } 8 \%\end{array}$ \\
\hline Kita et $\mathrm{al}^{95}$ & $\begin{array}{l}\text { Paclitaxel } 80 \mathrm{mg} / \mathrm{m}^{2} / \text { week in I-h infusion, } \\
3 \text { weeks on, I week off, and } \\
\text { repeated at least twice }\end{array}$ & $\begin{array}{l}37 \text { total } \\
14 \text { resistant }\end{array}$ & 29 & Neutropenia $24 \%$ \\
\hline Kaern et $\mathrm{a}^{96}$ & Weekly paclitaxel $80 \mathrm{mg} / \mathrm{m}^{2} / \mathrm{h}$ infusion & 57 & 56 & Grade 2 neutropenia 2 patients \\
\hline Rosenberg et $\mathrm{a}^{97}$ & $\begin{array}{l}\text { Weekly paclitaxel } 67 \mathrm{mg} / \mathrm{m}^{2} \text { vs } 3 \text { weekly } \\
\text { Paclitaxel } 200 \mathrm{mg} / \mathrm{m}^{2}\end{array}$ & 208 & $\begin{array}{l}\text { Similar efficacy } \\
\text { in two arms }\end{array}$ & $\begin{array}{l}\text { Grade 3-4 hematological and } \\
\text { non-hematological toxicity } \\
\text { occurred more frequently in } \\
\text { 3-weekly arm }\end{array}$ \\
\hline Havrilesky et al ${ }^{98}$ & $\begin{array}{l}\text { Carboplatin AUC } 2 \text { and paclitaxel at } \\
80 \mathrm{mg} / \mathrm{m}^{2} \text { on days I, } 8 \text {, and } 15 \text { on a } \\
28 \text {-day cycle }\end{array}$ & $\begin{array}{l}28 \text { Total } \\
8 \text { Resistant }\end{array}$ & 38 & Neutropenia $32 \%$ \\
\hline
\end{tabular}

Abbreviations: AUC, area under curve; IV, intravenous. 
neuropathy and one due to painful fingernail beds). ${ }^{93}$ In the second study, serious adverse events were relatively uncommon. ${ }^{94}$ Similarly, Kita et al used weekly paclitaxel by hourly infusion, with a $29 \%$ response in the platinumresistant setting. They reported Grade 3 or 4 neutropenia in $24 \%$ of their patients but there were no hospital admissions for neutropenic fever. ${ }^{95}$ In another study, 57 patients were treated with weekly paclitaxel with a response rate of $56 \%$, a median PFS of five months, and median OS of 13.7 months. Only two patients had Grade 2 neutropenia, and no neutropenic fever was recorded. ${ }^{96}$ Rosenberg et al compared three-weekly paclitaxel with one-third of the total dose used per week, the goal being to have similar total doses of paclitaxel in both arms of the trial. There was no difference in efficacy between the two arms, but less toxicity (other than fingernail toxicity) was observed in the weekly arm. ${ }^{97}$ In an innovative study of combination chemotherapy, Havrilesky et al used a reduced dose of carboplatin-paclitaxel on a weekly basis. In this study, eight platinum-refractory patients had a response rate of $37.5 \%$, while 21 platinum-sensitive patients had a 100\% response rate. Major toxicity in the form of Grade 3 neutropenia was seen in $32 \%$ of patients. ${ }^{98}$

\section{Paclitaxel maintenance therapy}

A randomized trial of 12 versus three months of maintenance paclitaxel at $175 \mathrm{mg} / \mathrm{m}^{2}$ over three hours every 28 days in 277 women after a complete response to initial therapy improved PFS (28 versus 21 months), but no difference in OS was observed either in the initial report or subsequent updates of the data. This study was stopped early by the Data Monitoring Committee when approximately half the proposed accrual had occurred due to the observed benefit in PFS, which was the proposed endpoint of the study. It was speculated that the lack of difference in the OS was due to underpowering of the study due to its early closure. In addition, treatment at relapse might have equalized the outcome. It is also noteworthy that the initial dose of paclitaxel was reduced in the trial from 175 to $135 \mathrm{mg} / \mathrm{m}^{2}$. The overall Grade 2/3 neuropathy rate in the trial was $14 \%$ and $18 \%$ in the control and treatment groups, respectively. ${ }^{99,100}$ In contrast, an Italian study reported by Pecorelli et al in 2009 randomized 200 women after initial complete response to either observation (ie, control) or six courses of paclitaxel $175 \mathrm{mg} / \mathrm{m}^{2}$ every three weeks and found no difference in PFS or OS. ${ }^{101}$

The GOG 212 trial is in progress comparing 12 cycles of paclitaxel versus 12 cycles of paclitaxel poliglumex versus observation until documented relapse, after a complete response to front-line therapy is achieved. This trial will hopefully resolve the controversy relating to the benefit of maintenance therapy.

\section{Addition of a third agent to carboplatin-paclitaxel}

Recently, several groups have tried to add a third agent to the paclitaxel-carboplatin doublet to exploit any potential clinical benefit. Du Bois et al added epirubicin and reported no benefit, ${ }^{102}$ whereas Scarfone et al added topotecan without any clinical benefit. ${ }^{103}$ In a landmark study of collaborative management of clinical trials, the GOG 182/ICON5 reported no evidence of clinical benefit from addition of topotecan, gemcitabine, or liposomal doxorubicin in the front-line treatment setting. ${ }^{104}$ However, encouraging results have been reported with addition of bevacizumab, the humanized monoclonal antibody against vascular endothelial growth factor. Two small Phase II trials reported good results and manageable toxicities. ${ }^{105,106}$ The "litmus test" of bevacizumab addition will be provided by GOG 218 and ICON7. GOG 218 is a randomized, double-blind, placebo-controlled, multicenter study, which is evaluating the paclitaxel-carboplatin doublet \pm bevacizumab, either for six courses or for 22 courses (http://clinicaltrials.gov/ct/show/ NCT00262847). ICON7 is testing a similar hypothesis, but the dose and duration of bevacizumab are different. This study finished recruiting 1528 patients in February 2009 and the results are pending.

\section{Paclitaxel in intraperitoneal chemotherapy}

Intraperitoneal (IP) spread presents one of the main routes of metastasis in epithelial ovarian cancer. Hence, the delivery of IP chemotherapy has always held theoretical promise, which investigators have tried to explore in at least three major randomized trials, two of which included paclitaxel.

Alberts et al $^{107}$ reported a trial of IV cisplatin-cyclophosphamide compared with IP cisplatin-cyclophosphamide, with a survival benefit in the IP arm of the study (41 versus 49 months). The main limitation of this study is that it preceded the paclitaxel era, and thus did not reflect contemporary therapy. Interestingly, the subset of patients with the lowest volume of disease did not demonstrate benefit from the IP approach.

In 2001, Markman et al ${ }^{108}$ reported a second major trial of 462 patients randomized to receive either IV paclitaxel $135 \mathrm{mg} / \mathrm{m}^{2}$ over 24 hours followed by IV cisplatin $75 \mathrm{mg} / \mathrm{m}^{2}$ every three weeks for six courses or IV carboplatin-AUC 9 
every 28 days for two courses, then IV paclitaxel $135 \mathrm{mg} / \mathrm{m}^{2}$ over 24 hours followed by IP cisplatin $100 \mathrm{mg} / \mathrm{m}^{2}$ every three weeks for six courses. This study reported a survival advantage in the IP arm (52.5 versus 63.2 months). This study has been criticized on the basis that more chemotherapy, rather than the IP route, may have resulted in the benefit because the patients in the IP arm received IV carboplatin-AUC 9 for two cycles before the IP therapy, representing a significant difference from the regimen used in the standard arm.

In January 2006, Armstrong et al published the results of GOG $172^{109}$ in which patients with optimally debulked Stage III ovarian carcinoma were randomly assigned to receive $135 \mathrm{mg} / \mathrm{m}^{2} / 24$ hours of IV paclitaxel followed by either $75 \mathrm{mg} / \mathrm{m}^{2}$ of IV cisplatin or $100 \mathrm{mg} / \mathrm{m}^{2}$ of IP cisplatin on day 2 and $60 \mathrm{mg} / \mathrm{m}^{2}$ of IP paclitaxel on day 8 (IP group). Treatment was given every three weeks for six cycles. Although only $42 \%$ of the patients in the IP arm completed six cycles of the assigned therapy. The median PFS was 18.3 versus 23.8 months, and the median OS was 49.7 versus 65.6 months, favoring the IP arm. Note that in this trial, the experimental arm used 24-hour IV paclitaxel followed by IP cisplatin on day 2 and IP paclitaxel on day 8 . The added day 8 paclitaxel regimen introduces another set of variables in addition to the mode of delivery of the therapy. Some argue that the results seen with GOG 172 are not significantly better than what can be achieved with the IV carboplatin and three-hour paclitaxel regimens. ${ }^{110-112}$ It is noteworthy that neutropenia, gastrointestinal toxicity, fatigue, pain, and metabolic events were increased in the IP arm. In addition, quality of life was significantly worse in the IP arm while on therapy but improved at the one-year follow-up. In addition, IP chemotherapy catheters caused abdominal pain, nausea, vomiting, infection, and fever.

On the basis of findings of increased survival with IP therapy in these three studies, the NCI issued a clinical advisory notice that recommended IP therapy be considered for women with ovarian cancer. Apart from the fact that IP therapy is more toxic, no IP regimen has so far been compared with what many consider to be the current standard, ie, IV carboplatin and paclitaxel..$^{112,113}$

\section{Resistance to paclitaxel}

Several mechanisms have been described to explain resistance to paclitaxel. The foremost are increased expression of the efflux transporter Pgp, multidrug resistance-associated protein 2 , and decreased expression of the influx transporter, ie, the organic anion transporting polypeptide $1 \mathrm{~B} 3$ (OATP1B3/SLCO1B3). ${ }^{24}$ Other possible mechanisms include overexpression of the paclitaxel-metabolizing enzyme CYP2C $8,{ }^{30}$ hypo-stable microtubules, mutations in tubulin that alter binding of paclitaxel, and alteration in the signaling pathways associated with microtubule function. ${ }^{21,24}$ Kavallaris et al demonstrated that resistance of epithelial ovarian cancer cell lines to paclitaxel is correlated with increased levels of Class I, III, and IVa B-tubulin isotypes. ${ }^{114}$ HER2/neu(c-erbB2) overexpression has also been implicated in paclitaxel resistance. ${ }^{15,116}$

MDR phenotype, which can be mediated by several multidrug transporters, particularly the 170-kDa Pgp efflux pump encoded by the $m d r 1$ gene, structurally altered $\alpha$ - and $\beta$-tubulins, and an impaired ability to polymerize tubulin dimers into microtubules. For example, high levels of the $\beta$ III isotype, a minor component of cellular $\beta$-tubulin that increases the dynamic instability of microtubules, impairs rates of microtubule assembly, and increases resistance to taxanes. ${ }^{117-119}$

\section{Toxicity Hematologic}

The major adverse effect of paclitaxel is myelosuppression, which mainly consists of neutropenia, whereas thrombocytopenia and anemia are uncommon. ${ }^{120}$ Neutropenia is more profound with higher doses, prolonged infusion, or if prior myelosuppressive therapy was used (eg, paclitaxel given after cisplatin). In the European-Canadian trial, the incidence of myelosuppression was $71 \%$ and $18 \%$ with 24 -hour and 3 -hour infusion, respectively, while febrile neutropenia was documented only in patients who received the 24-hour infusion. ${ }^{29}$ The neutropenia begins a week after paclitaxel infusion, nadirs in the second week, with complete recovery by the third week. Neutropenia does not reach lower levels with subsequent cycles, suggesting that toxicity is noncumulative. Paclitaxel has a platelet-sparing effect on thrombocytopenia produced by carboplatin. ${ }^{121}$ It is believed that clinically relevant doses of paclitaxel can be given without bone marrow supporting agents. ${ }^{122}$

\section{Hypersensitivity reactions}

Historically, the incidence of major hypersensitivity reactions to paclitaxel approached $30 \%$, but the incidence is down to $1 \%$ to $3 \%$ following widespread prophylactic use of steroids and antihistamine pretreatment. The vast majority of these events are minor (dyspnea, bronchospasm, urticaria, hypotension, rash, and itching). They typically occur within 
the first 10 minutes after the first or second cycle, respond well to supportive measures, and do not require cessation of therapy. Major reactions on the other hand are generally severe, eg, anaphylaxis, angioedema, or shock, and require cessation of therapy followed by emergent treatment. Usually, minor reactions do not indicate development of a major event. The hypersensitivity reactions are most likely caused by the polyoxyethylated castor oil vehicle, but the taxane moiety may also be contributory. It is noteworthy that in one large trial the incidence of major events was reported to be similar, irrespective of the infusion schedule used. ${ }^{29}$ Evidence suggests that the vast majority of patients may be successfully retreated with slow, low-dose infusions of paclitaxel after premedication with appropriate desensitization schedules. Markman et al reported a 100\% success rate with taxane rechallenge in 44 patients with their regimen. ${ }^{123}$

\section{Neuromuscular}

In contrast with myelosuppression, peripheral neuropathy is cumulative and progressive with increasing exposure to the drug, but usually disappears several weeks or months after discontinuation of paclitaxel. Neuropathy due to paclitaxel presents as numbness and paresthesia in a gloveand-stocking distribution. It is usually symmetric, sensory as well as motor, and affects proprioception, vibration, temperature, and pinprick sensation. The time of onset is typically several weeks at conventional doses (135 to $\left.250 \mathrm{mg} / \mathrm{m}^{2}\right)$, and quicker (24-72 hours) at higher doses $\left(>250 \mathrm{mg} / \mathrm{m}^{2}\right)$. The most commonly affected sites include the limbs, face (perioral numbness), optic nerve (scintillating scotoma), joints, and the autonomic nervous system. Risk factors include longer treatment, higher doses, alcohol, diabetes, and preexisting neuropathy. Transient muscle pains are common, and frank myopathy may occur at doses higher than $250 \mathrm{mg} / \mathrm{m}^{2}$ or in combination with platinum agents. Unlike hematologic toxicity, neuropathy is observed more frequently with shorter infusion schedules (less than three hours).

The management of paclitaxel-induced neuropathy is a matter of intense research. Although multiple agents have been proposed to ameliorate nerve damage, few have been studied, and with mixed results. Amitriptyline and gabapentin have been used in neuropathic pain with success. Neuroprotective agents in the form of high dose vitamin E, glutamine, lamotrigine, and disodium 2,20-dithio-bisethanesulfonate (BNP7787, which is reduced to mesna) all have preliminary data in their support but await large-scale trials to validate their widespread use. ${ }^{124}$

\section{Cardiac}

In the initial clinical trials of paclitaxel, routine cardiac monitoring was performed due to a high rate of hypersensitivity reactions. This led to the detection of a relatively high rate of cardiac rhythm disturbances, the relevance of which is doubtful because the vast majority of patients remained asymptomatic. Therefore, routine cardiac monitoring of patients receiving paclitaxel is no longer required. Nevertheless, the most common rhythm disturbance appears to be asymptomatic transient bradycardia. Mobitz Type I (Wenckebach phenomenon), Mobitz Type II, and third-degree heart block have also been noted, but the incidence in a large NCI database was only $0.1 \% .{ }^{125}$

There is no evidence that chronic paclitaxel use causes cardiac dysfunction. However, cardiac monitoring should be considered for patients with atrioventricular conduction disturbances or ventricular dysfunction. Doxorubicin used with paclitaxel increases cardiac toxicity more than what would be expected with the former alone. Dexrazoxane may help reduce cardiotoxicity in this setting but the data remain preliminary. ${ }^{126-129}$ In a Phase III trial of trastuzumabpaclitaxel in breast cancer, the incidence of cardiotoxicity was increased, warranting careful patient monitoring. ${ }^{130}$

\section{Gastrointestinal}

Paclitaxel-induced gastrointestinal effects are generally uncommon and limited to mild nausea, mucositis, diarrhea, and elevated liver function tests, so routine use of antiemetics is not recommended. Rare cases of neutropenic enterocolitis, gastrointestinal necrosis, ${ }^{131}$ typhlitis, ${ }^{132}$ hepatotoxicity, ${ }^{133}$ and pancreatitis ${ }^{134}$ have been reported, especially with high doses of paclitaxel in combination with doxorubicin or cyclophosphamide.

\section{Dermatologic}

Paclitaxel induces reversible alopecia of the scalp. Extravasations of large volumes can cause moderate soft tissue injury, and rare reports of nail disorders and recall reactions at previously irradiated sites have also been noted, although mostly with weekly schedules only. ${ }^{23}$

\section{Newer forms of paclitaxel}

Several newer forms of paclitaxel have been manufactured, aimed at decreasing toxicity, increasing efficacy, and improving ease of administration. Abraxane ${ }^{\circledR}$ is an albuminbound form of paclitaxel which delivers paclitaxel as a suspension of albumin nanoparticles in saline, eliminating the need for Cremophor EL, the traditional carrier for the drug. 
Cremophor EL is considered a key factor in hypersensitivity reactions to paclitaxel, leading to slower infusion rates and a need for premedication. Abraxane may eliminate these limitations and offers the additional advantages of delivery of a relatively higher dose of paclitaxel. Fader et al successfully treated five patients with severe hypersensitivity reactions to traditional paclitaxel with 80 to $100 \mathrm{mg} / \mathrm{m}^{2}$ of Abraxane in gynecologic cancers. ${ }^{135}$

Abraxane may also increase intratumoral concentration of paclitaxel by a receptor-mediated transport process across the endothelial cell wall, thereby breaching the blood/tumor interface. ${ }^{136}$ Although Abraxane has demonstrated a high degree of activity in metastatic breast and lung cancer, ${ }^{137,138}$ its toxicity profile and response rates in ovarian cancer remain to be elucidated in a large number of patients. In a Phase II study, Teneriello et al treated patients with recurrent platinum-sensitive disease using Abraxane $260 \mathrm{mg} / \mathrm{m}^{2}$ for 30 minutes on day 1 of a 21-day cycle for six cycles or until disease progression. The response rate was 64\% (15 complete and 13 partial responses among 44 assessable patients). Estimated median PFS was 8.5 months. The most frequent Grade 3-4 toxicities were neutropenia (24\%) and neuropathy (9\%). ${ }^{139}$ Several other trials of this formulation are in progress.

Taxoprexin ${ }^{\circledR}$ is paclitaxel bound to docosahexaenoic acid (DHA), a fatty acid that is easily taken up by tumor cells. Upon entry of this prodrug into the cell, normal metabolism cleaves the fatty acid moiety to yield the active drug. The main advantage of DHA-paclitaxel is its ability to carry much higher concentrations of paclitaxel to the cells. ${ }^{140}$

Paclitaxel poliglumex is a conjugate of paclitaxel and poly-L-glutamic acid which accumulates in tumor tissue due to enhanced permeability of the tumor vasculature and lack of lymphatic drainage. Paclitaxel poliglumex prolongs exposure to the active drug and minimizes systemic exposure. In a Phase II GOG study of relapsed ovarian cancer, a response rate of $16 \%$ was seen, with Grade 3 and 4 toxicities being neutropenia ( $24 \%$ and $20 \%$, respectively), constitutional symptoms ( $8 \%$ and $0 \%$ ), gastrointestinal disturbance $(6 \%$ and $0 \%)$, and neuropathy $(24 \%$ and $0 \%) .{ }^{141}$

ANG1005, another newer form of paclitaxel, is made up of one molecule of angiopep-2 (brain peptide vector) joined together with three molecules of paclitaxel. ANG1005 enters the brain to a greater extent than paclitaxel and bypasses the Pgp efflux pump mechanism. ${ }^{142}$ This formulation gives new hope for treatment of brain metastasis from various forms of tumors.

\section{Patient perspectives}

Quality of life, although an important consideration, has not in the past been the primary endpoint of front-line chemotherapy trials, because OS is considered the most important issue. It is believed that patients will prefer a therapy which prolongs life at the expense of nonthreatening toxicities impacting quality of life. However, this notion is not true for recurrent ovarian cancer where cure is not yet possible and therefore palliation of symptoms and toxicities is of critical value. Because the dosing strategy for paclitaxel has a great impact on its toxicity profile and hence quality of life, the better tolerated weekly low-dose paclitaxel regimens are fast emerging as the preferred therapy in recurrent ovarian cancer. $^{99,100}$

\section{Conclusions}

In past two decades, taxanes have emerged as front-line chemotherapy agents in several types of human cancers. Paclitaxel for ovarian cancer epitomizes this notion and is the current standard front-line therapy along with carboplatin. Having already learned about the efficacy of paclitaxel in ovarian cancer, future areas of active exploration include finding the optimal dosing schedule, investigating newer and potentially better forms of paclitaxel, and identifying the optimal route of administration.

\section{Disclosure}

The authors declare no conflicts of interest in this work.

\section{References}

1. Jemal A, Siegel R, Ward E, et al. Cancer statistics, 2008. CA Cancer J Clin. 2008;58:71-96.

2. Goodman MT, Howe HL, Tung KH, et al. Incidence of ovarian cancer by race and ethnicity in the United States, 1992-1997. Cancer. 2003;97:2676-2685.

3. Chiaffarino F, Parazzini F, Bosetti C, et al. Risk factors for ovarian cancer histotypes. Eur J Cancer. 2007;43:1208-1213.

4. Soegaard M, Jensen A, Hogdall E, et al. Different risk factor profiles for mucinous and nonmucinous ovarian cancer: Results from the Danish MALOVA study. Cancer Epidemiol Biomarkers Prev. 2007;16: $1160-1166$.

5. Chan JK, Urban R, Cheung MK, et al. Ovarian cancer in younger vs older women: A population-based analysis. $\mathrm{Br} J$ Cancer. 2006;95:1314-1320.

6. Wani MC, Taylor HL, Wall ME, Coggon P, McPhail AT. Plant antitumor agents. VI. The isolation and structure of taxol, a novel antileukemic and antitumor agent from Taxus brevifolia. J Am Chem Soc. 1971;93:2325-2327.

7. Schiff PB, Fant J, Horwitz SB. Promotion of microtubule assembly in vitro by taxol. Nature. 1979;277:665-667.

8. Oberlies NH, Kroll DJ. Camptothecin and taxol: Historic achievements in natural products research. J Nat Prod. 2004;67:129-135.

9. Pazdur R, Kudelka AP, Kavanagh JJ, Cohen PR, Raber MN. The taxoids: Paclitaxel (Taxol) and docetaxel (Taxotere). Cancer Treat Rev. 1993;19:351-386. 
10. Miller ML, Ojima I. Chemistry and chemical biology of taxane anticancer agents. Chem Rec. 2001;1:195-211.

11. Orr GA, Verdier-Pinard P, McDaid H, Horwitz SB. Mechanisms of Taxol resistance related to microtubules. Oncogene. 2003;22: $7280-7295$.

12. Downing KH. Structural basis for the interaction of tubulin with proteins and drugs that affect microtubule dynamics. Annu Rev Cell Dev Biol. 2000;16:89-111.

13. Jordan A, Hadfield JA, Lawrence NJ, McGown AT. Tubulin as a target for anticancer drugs: Agents which interact with the mitotic spindle. Med Res Rev. 1998;18:259-296.

14. Correia JJ, Lobert S. Physiochemical aspects of tubulin-interacting antimitotic drugs. Curr Pharm Res. 2001;7:1213-1228.

15. Foa R, Norton L, Seidman AD. Taxol (paclitaxel): A novel antimicrotubule agent with remarkable anti-neoplastic activity. Int J Clin Lab Res. 1994;24:6-14.

16. Giannakakou P, Poy G, Zhan Z, Knutsen T, Blagosklonny MV, Fojo T. Paclitaxel selects for mutant or pseudo-null p53 in drug resistance associated with tubulin mutations in human cancer. Oncogene. 2000;19:3078-3085.

17. Schmidt M, Lu Y, Liu B, Fang M, Mendelsohn J, Fan Z. Differential modulation of paclitaxel-mediated apoptosis by $\mathrm{p} 21 \mathrm{Waf1}$ and $\mathrm{p} 27 \mathrm{Kip} 1$. Oncogene. 2000;19:2423-2429.

18. Wang LG, Liu XM, Kreis W, Budman DR. The effect of antimicrotubule agents on signal transduction pathways of apoptosis: A review. Cancer Chemother Pharmacol. 1999;44:355-361.

19. Ganansia-Leymarie V, Bischoff P, Bergerat JP, Holl V. Signal transduction pathways of taxanes-induced apoptosis. Curr Med Chem Anticancer Agents. 2003;3:291-306.

20. Lesser GJ, Grossman SA, Eller S, Rowinsky EK. The distribution of systemically administered 3H-paclitaxel in rats: A quantitative autoradiographic study. Cancer Chemother Pharmacol. 1995;37: 173-178.

21. Rowinsky EK. Pharmacology and metabolism. In: Paclitaxel in Cancer Treatment. New York, NY: Marcel Dekker; 1995.

22. Eisenhauer EA, Vermorken JB. The taxoids. Comparative clinical pharmacology and therapeutic potential. Drugs. 1998;55:5-30.

23. Michaud LB, Valero V, Hortobagyi G. Risks and benefits of taxanes in breast and ovarian cancer. Drug Saf. 2000;23:401-428.

24. Walle T, Walle UK, Kumar GN, Bhalla KN. Taxol metabolism and disposition in cancer patients. Drug Metab Dispos. 1995;23: 506-512.

25. Monsarrat B, Alvinerie P, Wright M, et al. Hepatic metabolism and biliary excretion of Taxol in rats and humans. J Natl Cancer Inst Monogr. 1993:39-46.

26. Markman M, Rose PG, Jones E, et al. Ninety-six-hour infusional paclitaxel as salvage therapy of ovarian cancer patients previously failing treatment with 3-hour or 24-hour paclitaxel infusion regimens. J Clin Oncol. 1998;16:1849-1851.

27. Spriggs DR, Brady MF, Vaccarello L, et al. Phase III randomized trial of intravenous cisplatin plus a 24- or 96-hour infusion of paclitaxel in epithelial ovarian cancer: A Gynecologic Oncology Group Study. J Clin Oncol. 2007;25:4466-4471.

28. Rowinsky EK. The taxanes: Dosing and scheduling considerations. Oncology (Williston Park). 1997;11:7-19.

29. Eisenhauer EA, ten Bokkel Huinink WW, Swenerton KD, et al. European-Canadian randomized trial of paclitaxel in relapsed ovarian cancer: High-dose versus low-dose and long versus short infusion. J Clin Oncol. 1994;12:2654-2666.

30. Bolis G, Scarfone G, Polverino G, et al. Paclitaxel 175 or $225 \mathrm{mg}$ per meters squared with carboplatin in advanced ovarian cancer: A randomized trial. J Clin Oncol. 2004;22:686-690.

31. Omura GA, Brady MF, Look KY, et al. Phase III trial of paclitaxel at two dose levels, the higher dose accompanied by filgrastim at two dose levels in platinum-pretreated epithelial ovarian cancer: An intergroup study. J Clin Oncol. 2003;21:2843-2848.
32. Katsumata N, Yasuda M, Takahashi F, et al. Dose-dense paclitaxel once a week in combination with carboplatin every 3 weeks for advanced ovarian cancer: A phase 3, open-label, randomised controlled trial. Lancet. 2009;374:1331-1338.

33. Fennelly D, Aghajanian C, Shapiro F, et al. Phase I and pharmacologic study of paclitaxel administered weekly in patients with relapsed ovarian cancer. J Clin Oncol. 1997;15:187-192.

34. Bookman MA. Dose-dense chemotherapy in advanced ovarian cancer. Lancet. 2009;374:1303-1305.

35. Sehouli J, Stengel D, Mustea A, et al. Weekly paclitaxel and carboplatin (PC-W) for patients with primary advanced ovarian cancer: Results of a multicenter phase-II study of the NOGGO. Cancer Chemother Pharmacol. 2008;61:243-250.

36. Rose PG, Smrekar M, Fusco N. A phase II trial of weekly paclitaxel and every 3 weeks of carboplatin in potentially platinumsensitive ovarian and peritoneal carcinoma. Gynecol Oncol. 2005;96: 296-300.

37. Pignata S, Breda E, Scambia G, et al. A phase II study of weekly carboplatin and paclitaxel as first-line treatment of elderly patients with advanced ovarian cancer. A Multicentre Italian Trial in Ovarian cancer (MITO-5) study. Crit Rev Oncol Hematol. 2008;66:229-236.

38. Rowinsky EK, Gilbert MR, McGuire WP, et al. Sequences of taxol and cisplatin: A phase I and pharmacologic study. J Clin Oncol. 1991;9:1692-1703.

39. Efferth T, Fabry U, Osieka R. Damage of the kinesin heavy chain gene contributes to the antagonism of cisplatin and paclitaxel. Anticancer Res. 2000;20:3211-3219.

40. Huizing MT, Keung AC, Rosing H, et al. Pharmacokinetics of paclitaxel and metabolites in a randomized comparative study in platinum-pretreated ovarian cancer patients. J Clin Oncol. 1993;11: 2127-2135.

41. Belani CP, Kearns CM, Zuhowski EG, et al. Phase I trial, including pharmacokinetic and pharmacodynamic correlations, of combination paclitaxel and carboplatin in patients with metastatic non-small-cell lung cancer. J Clin Oncol. 1999;17:676-684.

42. Huizing MT, van Warmerdam LJ, Rosing H, et al. Phase I and pharmacologic study of the combination paclitaxel and carboplatin as firstline chemotherapy in stage III and IV ovarian cancer. J Clin Oncol. 1997;15:1953-1964.

43. Baker AF, Dorr RT. Drug interactions with the taxanes: Clinical implications. Cancer Treat Rev. 2001;27:221-233.

44. Sparano JA. Use of dexrazoxane and other strategies to prevent cardiomyopathy associated with doxorubicin-taxane combinations. Semin Oncol. 1998;25:66-71.

45. Perez EA, Buckwalter CA. Sequence-dependent cytotoxicity of etoposide and paclitaxel in human breast and lung cancer cell lines. Cancer Chemother Pharmacol. 1998;41:448-452.

46. Budman DR, Calabro A, Kreis W. In vitro evaluation of synergism or antagonism with combinations of new cytotoxic agents. Anticancer Drugs. 1998;9:697-702.

47. Seidman A, Hudis C, Pierri MK, et al. Cardiac dysfunction in the trastuzumab clinical trials experience. J Clin Oncol. 2002;20: $1215-1221$.

48. Fetell MR, Grossman SA, Fisher JD, et al. Preirradiation paclitaxel in glioblastoma multiforme: Efficacy, pharmacology, and drug interactions. New Approaches to Brain Tumor Therapy Central Nervous System Consortium. J Clin Oncol. 1997;15:3121-3128.

49. Prados MD, Schold SC, Spence AM, et al. Phase II study of paclitaxel in patients with recurrent malignant glioma. J Clin Oncol. 1996;14: 2316-2321.

50. Robert F, Ozols SCR, Thomas GM, Robboy SJ. Epithelial ovarian cancer. In: Hoskins WJ, editor. Principles and Practice of Gynecologic Oncology. 4th ed. Philadelphia, PA: Lippincott Williams \& Wilkins; 2005.

51. Bell J, Brady MF, Young RC, et al. Randomized phase III trial of three versus six cycles of adjuvant carboplatin and paclitaxel in early stage epithelial ovarian carcinoma: A Gynecologic Oncology Group study. Gynecol Oncol. 2006;102:432-439. 
52. Markman M. Re: "Randomized phase III trial of three versus six cycles of adjuvant carboplatin and paclitaxel in early stage epithelial ovarian carcinoma: A Gynecologic Oncology Group study". Gynecol Oncol. 2007;105:279-280; author reply 280-281.

53. Rowinsky EK, Burke PJ, Karp JE, Tucker RW, Ettinger DS, Donehower RC. Phase I and pharmacodynamic study of taxol in refractory acute leukemias. Cancer Res. 1989;49:4640-4647.

54. Donehower RC, Rowinsky EK, Grochow LB, Longnecker SM, Ettinger DS. Phase I trial of taxol in patients with advanced cancer. Cancer Treat Rep. 1987;71:1171-1177.

55. Rowinsky EK, Donehower RC, Jones RJ, Tucker RW. Microtubule changes and cytotoxicity in leukemic cell lines treated with taxol. Cancer Res. 1988;48:4093-4100.

56. Spriggs DR, Tondini C. Taxol administered as a 120 hour infusion. Invest New Drugs. 1992;10:275-278.

57. Thigpen JT, Blessing JA, Ball H, Hummel SJ, Barrett RJ. Phase II trial of paclitaxel in patients with progressive ovarian carcinoma after platinum-based chemotherapy: A Gynecologic Oncology Group study. J Clin Oncol. 1994;12:1748-1753.

58. Einzig AI, Wiernik PH, Sasloff J, Runowicz CD, Goldberg GL. Phase II study and long-term follow-up of patients treated with taxol for advanced ovarian adenocarcinoma. J Clin Oncol. 1992;10:1748-1753.

59. McGuire WP, Hoskins WJ, Brady MF, et al. Cyclophosphamide and cisplatin compared with paclitaxel and cisplatin in patients with stage III and stage IV ovarian cancer. N Engl J Med. 1996;334:1-6.

60. Piccart MJ, Bertelsen K, James K, et al. Randomized intergroup trial of cisplatin-paclitaxel versus cisplatin-cyclophosphamide in women with advanced epithelial ovarian cancer: Three-year results. J Natl Cancer Inst. 2000;92:699-708.

61. Muggia FM, Braly PS, Brady MF, et al. Phase III randomized study of cisplatin versus paclitaxel versus cisplatin and paclitaxel in patients with suboptimal stage III or IV ovarian cancer: A Gynecologic Oncology Group study. J Clin Oncol. 2000;18:106-115.

62. Paclitaxel plus carboplatin versus standard chemotherapy with either single-agent carboplatin or cyclophosphamide, doxorubicin, and cisplatin in women with ovarian cancer: The ICON3 randomised trial. Lancet. 2002;360:505-515.

63. Sandercock J, Parmar MK, Torri V, Qian W. First-line treatment for advanced ovarian cancer: Paclitaxel, platinum and the evidence. $\mathrm{Br} J$ Cancer. 2002;87:815-824.

64. Neijt JP, Engelholm SA, Tuxen MK, et al. Exploratory phase III study of paclitaxel and cisplatin versus paclitaxel and carboplatin in advanced ovarian cancer. J Clin Oncol. 2000;18:3084-3092.

65. du Bois A, Luck HJ, Meier W, et al. A randomized clinical trial of cisplatin/paclitaxel versus carboplatin/paclitaxel as first-line treatment of ovarian cancer. J Natl Cancer Inst. 2003;95:1320-1329.

66. Ozols RF, Bundy BN, Greer BE, et al. Phase III trial of carboplatin and paclitaxel compared with cisplatin and paclitaxel in patients with optimally resected stage III ovarian cancer: A Gynecologic Oncology Group study. J Clin Oncol. 2003;21:3194-3200.

67. Cannistra SA. Cancer of the ovary. N Engl J Med. 2004;351:2519-2529.

68. Thigpen JT, Vance RB, Khansur T. Second-line chemotherapy for recurrent carcinoma of the ovary. Cancer. 1993;71:1559-1564.

69. Ozols RF. Treatment goals in ovarian cancer. Int J Gynecol Cancer. 2005;15 Suppl 1:3-11.

70. Wright JD, Hagemann A, Rader JS, et al. Bevacizumab combination therapy in recurrent, platinum-refractory, epithelial ovarian carcinoma: A retrospective analysis. Cancer. 2006;107:83-89.

71. Keldsen N, Havsteen H, Vergote I, Bertelsen K, Jakobsen A. Altretamine (hexamethylmelamine) in the treatment of platinumresistant ovarian cancer: A phase II study. Gynecol Oncol. 2003;88: 118-122.

72. Muggia FM, Hainsworth JD, Jeffers S, et al. Phase II study of liposomal doxorubicin in refractory ovarian cancer: Antitumor activity and toxicity modification by liposomal encapsulation. J Clin Oncol. 1997;15:987-993.
73. Gordon AN, Fleagle JT, Guthrie D, Parkin DE, Gore ME, Lacave AJ. Recurrent epithelial ovarian carcinoma: A randomized phase III study of pegylated liposomal doxorubicin versus topotecan. J Clin Oncol. 2001;19:3312-3322.

74. Bookman MA, Malmstrom H, Bolis G, et al. Topotecan for the treatment of advanced epithelial ovarian cancer: An open-label phase II study in patients treated after prior chemotherapy that contained cisplatin or carboplatin and paclitaxel. J Clin Oncol. 1998;16: 3345-3352.

75. Hoskins P, Eisenhauer E, Beare S, et al. Randomized phase II study of two schedules of topotecan in previously treated patients with ovarian cancer: A National Cancer Institute of Canada Clinical Trials Group study. J Clin Oncol. 1998;16:2233-2237.

76. Lund B, Hansen OP, Theilade K, Hansen M, Neijt JP. Phase II study of gemcitabine (2',2'-difluorodeoxycytidine) in previously treated ovarian cancer patients. J Natl Cancer Inst. 1994;86: $1530-1533$.

77. Rose PG, Mossbruger K, Fusco N, Smrekar M, Eaton S, Rodriguez M. Gemcitabine reverses cisplatin resistance: Demonstration of activity in platinum- and multidrug-resistant ovarian and peritoneal carcinoma. Gynecol Oncol. 2003;88:17-21.

78. Petru E, Angleitner-Boubenizek L, Reinthaller A, et al. Combined PEG liposomal doxorubicin and gemcitabine are active and have acceptable toxicity in patients with platinum-refractory and -resistant ovarian cancer after previous platinum-taxane therapy: A phase II Austrian AGO study. Gynecol Oncol. 2006;102:226-229.

79. Slayton RE, Creasman WT, Petty W, Bundy B, Blessing JA. Phase II trial of VP-16-213 in the treatment of advanced squamous cell carcinoma of the cervix and adenocarcinoma of the ovary: A Gynecologic Oncology Group Study. Cancer Treat Rep. 1979;63:2089-2092.

80. Rose PG, Blessing JA, Mayer AR, Homesley HD. Prolonged oral etoposide as second-line therapy for platinum-resistant and platinumsensitive ovarian carcinoma: A Gynecologic Oncology Group study. $J$ Clin Oncol. 1998;16:405-410.

81. Markman M, Kennedy A, Sutton G, et al. Phase 2 trial of single agent ifosfamide/mesna in patients with platinum/paclitaxel refractory ovarian cancer who have not previously been treated with an alkylating agent. Gynecol Oncol. 1998;70:272-274.

82. ten Bokkel Huinink W, Gore M, Carmichael J, et al. Topotecan versus paclitaxel for the treatment of recurrent epithelial ovarian cancer. J Clin Oncol. 1997;15:2183-2193.

83. ten Bokkel Huinink W, Lane SR, Ross GA. Long-term survival in a phase III, randomised study of topotecan versus paclitaxel in advanced epithelial ovarian carcinoma. Ann Oncol. 2004;15:100-103.

84. Piccart MJ, Green JA, Lacave AJ, et al. Oxaliplatin or paclitaxel in patients with platinum-pretreated advanced ovarian cancer: A randomized phase II study of the European Organization for Research and Treatment of Cancer Gynecology Group. J Clin Oncol. 2000;18:1193-1202.

85. Cantu MG, Buda A, Parma G, et al. Randomized controlled trial of single-agent paclitaxel versus cyclophosphamide, doxorubicin, and cisplatin in patients with recurrent ovarian cancer who responded to first-line platinum-based regimens. J Clin Oncol. 2002;20: $1232-1237$.

86. Gronlund B, Hogdall C, Hansen HH, Engelholm SA. Results of reinduction therapy with paclitaxel and carboplatin in recurrent epithelial ovarian cancer. Gynecol Oncol. 2001;83:128-134.

87. Gonzalez-Martin AJ, Calvo E, Bover I, et al. Randomized phase II trial of carboplatin versus paclitaxel and carboplatin in platinum-sensitive recurrent advanced ovarian carcinoma: A GEICO (Grupo Espanol de Investigacion en Cancer de Ovario) study. Ann Oncol. 2005;16: 749-755.

88. Parmar MK, Ledermann JA, Colombo N, et al. Paclitaxel plus platinumbased chemotherapy versus conventional platinum-based chemotherapy in women with relapsed ovarian cancer: The ICON4/AGO-OVAR-2.2 trial. Lancet. 2003;361:2099-2106. 
89. Buda A, Floriani I, Rossi R, et al. Randomised controlled trial comparing single agent paclitaxel vs epidoxorubicin plus paclitaxel in patients with advanced ovarian cancer in early progression after platinum-based chemotherapy: An Italian Collaborative Study from the Mario Negri Institute, Milan, G.O.N.O. (Gruppo Oncologico Nord Ovest) group and I.O.R. (Istituto Oncologico Romagnolo) group. $\mathrm{Br}$ J Cancer. 2004;90:2112-2117.

90. Pujade-Lauraine E, Kaern J, Gebski V, et al; GINECO, Paris, France; AGO-OVAR, Hamburg, Germany; NSGO, Oslo, Norway; ANZGOG, Sydney, Australia; NCIC Clinical Trials Group, Vancouver, BC, Canada; ANZGOG, Queensland, Australia; AGO-Austria, Vienna, Austria; EORTC, Leuven, Belgium; MITO, Napoli, Italy; MANGO, Torino, Italy. A randomized, phase III study of carboplatin and pegylated liposomal doxorubicin versus carboplatin and paclitaxel in relapsed platinum-sensitive ovarian cancer (OC): CALYPSO study of the Gynecologic Cancer Intergroup (GCIG). In: American Society of Clinical Oncology: American Society of Cancer; 2009. Available at http://www.calypso-study.org/. Accessed August 27, 2010.

91. McGuire WP, Rowinsky EK, Rosenshein NB, et al. Taxol: A unique antineoplastic agent with significant activity in advanced ovarian epithelial neoplasms. Ann Intern Med. 1989;111:273-279.

92. Kohn EC, Sarosy G, Bicher A, et al. Dose-intense taxol: High response rate in patients with platinum-resistant recurrent ovarian cancer. $J$ Natl Cancer Inst. 1994;86:18-24.

93. Markman M, Hall J, Spitz D, et al. Phase II trial of weekly singleagent paclitaxel in platinum/paclitaxel-refractory ovarian cancer. J Clin Oncol. 2002;20:2365-2369.

94. Markman M, Blessing J, Rubin SC, Connor J, Hanjani P, Waggoner S. Phase II trial of weekly paclitaxel $\left(80 \mathrm{mg} / \mathrm{m}^{2}\right)$ in platinum and paclitaxel-resistant ovarian and primary peritoneal cancers: A Gynecologic Oncology Group study. Gynecol Oncol. 2006;101:436-440.

95. Kita T, Kikuchi Y, Takano M, et al. The effect of single weekly paclitaxel in heavily pretreated patients with recurrent or persistent advanced ovarian cancer. Gynecol Oncol. 2004;92:813-818.

96. Kaern J, Baekelandt M, Trope CG. A phase II study of weekly paclitaxel in platinum and paclitaxel-resistant ovarian cancer patients. Eur J Gynaecol Oncol. 2002;23:383-389.

97. Rosenberg P, Andersson H, Boman K, et al. Randomized trial of single agent paclitaxel given weekly versus every three weeks and with peroral versus intravenous steroid premedication to patients with ovarian cancer previously treated with platinum. Acta Oncol. 2002;41:418-424

98. Havrilesky LJ, Alvarez AA, Sayer RA, et al. Weekly low-dose carboplatin and paclitaxel in the treatment of recurrent ovarian and peritoneal cancer. Gynecol Oncol. 2003;88:51-57.

99. Markman M, Liu PY, Wilczynski S, et al. Phase III randomized trial of 12 versus 3 months of maintenance paclitaxel in patients with advanced ovarian cancer after complete response to platinum and paclitaxel-based chemotherapy: A Southwest Oncology Group and Gynecologic Oncology Group trial. J Clin Oncol. 2003;21: 2460-2465.

100. Markman M, Liu PY, Moon J, et al. Impact on survival of 12 versus 3 monthly cycles of paclitaxel $\left(175 \mathrm{mg} / \mathrm{m}^{2}\right)$ administered to patients with advanced ovarian cancer who attained a complete response to primary platinum-paclitaxel: Follow-up of a Southwest Oncology Group and Gynecologic Oncology Group phase 3 trial. Gynecol Oncol. 2009;114:195-198.

101. Pecorelli S, Favalli G, Gadducci A, et al. Phase III trial of observation versus six courses of paclitaxel in patients with advanced epithelial ovarian cancer in complete response after six courses of paclitaxel/ platinum-based chemotherapy: Final results of the After-6 protocol 1. J Clin Oncol. 2009;27:4642-4648.

102. du Bois A, Weber B, Rochon J, et al. Addition of epirubicin as a third drug to carboplatin-paclitaxel in first-line treatment of advanced ovarian cancer: A prospectively randomized gynecologic cancer intergroup trial by the Arbeitsgemeinschaft Gynaekologische Onkologie Ovarian Cancer Study Group and the Groupe d'Investigateurs Nationaux pour l'Etude des Cancers Ovariens. J Clin Oncol. 2006;24: 1127-1135.
103. Scarfone G, Scambia G, Raspagliesi F, et al. A multicenter, randomized, phase III study comparing paclitaxel/carboplatin (PC) versus topotecan/paclitaxel/carboplatin (TPC) in patients with stage III (residual tumor $>1 \mathrm{~cm}$ after primary surgery) and IV ovarian cancer (OC). 2006 ASCO Annual Meeting Proceedings, Part I. J Clin Oncol. 2006;24(18S):5003.

104. Bookman MA, Brady MF, McGuire WP, et al. Evaluation of new platinum-based treatment regimens in advanced-stage ovarian cancer: A Phase III Trial of the Gynecologic Cancer Intergroup. J Clin Oncol. 2009;27:1419-1425.

105. Penson RT, Dizon DS, Cannistra SA, et al. Phase II study of carboplatin, paclitaxel, and bevacizumab with maintenance bevacizumab as first-line chemotherapy for advanced mullerian tumors. J Clin Oncol. 28:154-159.

106. Micha JP, Goldstein BH, Rettenmaier MA, et al. A phase II study of outpatient first-line paclitaxel, carboplatin, and bevacizumab for advanced-stage epithelial ovarian, peritoneal, and fallopian tube cancer. Int J Gynecol Cancer. 2007;17:771-776.

107. Alberts DS, Liu PY, Hannigan EV, et al. Intraperitoneal cisplatin plus intravenous cyclophosphamide versus intravenous cisplatin plus intravenous cyclophosphamide for stage III ovarian cancer. $N$ Engl J Med. 1996;335:1950-1955.

108. Markman M, Bundy BN, Alberts DS, et al. Phase III trial of standarddose intravenous cisplatin plus paclitaxel versus moderately high-dose carboplatin followed by intravenous paclitaxel and intraperitoneal cisplatin in small-volume stage III ovarian carcinoma: an intergroup study of the Gynecologic Oncology Group, Southwestern Oncology Group, and Eastern Cooperative Oncology Group. J Clin Oncol. 2001;19:1001-1007.

109. Armstrong DK, Bundy B, Wenzel L, et al. Intraperitoneal cisplatin and paclitaxel in ovarian cancer. $N$ Engl J Med. 2006;354: 34-43.

110. Ozols RF, Bookman MA, du Bois A, Pfisterer J, Reuss A, Young RC. Intraperitoneal cisplatin therapy in ovarian cancer: comparison with standard intravenous carboplatin and paclitaxel. Gynecol Oncol. 2006;103:1-6.

111. Ozols RF, Bookman MA, Young RC. Intraperitoneal chemotherapy for ovarian cancer. $N$ Engl J Med. 2006;354:1641-1643 author reply 1641-1643.

112. Alberts DS, Markman M, Muggia F, et al. Proceedings of a GOG workshop on intraperitoneal therapy for ovarian cancer. Gynecol Oncol. 2006;103:783-792.

113. Swart AM, Burdett S, Ledermann J, Mook P, Parmar MK. Why i.p. therapy cannot yet be considered as a standard of care for the firstline treatment of ovarian cancer: A systematic review. Ann Oncol. 2008;19:688-695.

114. Kavallaris M, Kuo DY, Burkhart CA, et al. Taxol-resistant epithelial ovarian tumors are associated with altered expression of specific beta-tubulin isotypes. J Clin Invest. 1997;100:1282-1293.

115. Gottesman MM, Fojo T, Bates SE. Multidrug resistance in cancer: Role of ATP-dependent transporters. Nat Rev Cancer. 2002;2:48-58.

116. Rowinsky EK, Smith L, Wang YM, et al. Phase I and pharmacokinetic study of paclitaxel in combination with biricodar, a novel agent that reverses multidrug resistance conferred by overexpression of both MDR1 and MRP. J Clin Oncol. 1998;16:2964-2976.

117. Gonzalez-Garay ML, Chang L, Blade K, Menick DR, Cabral F. A beta-tubulin leucine cluster involved in microtubule assembly and paclitaxel resistance. J Biol Chem. 1999;274:23875-23882.

118. Giannakakou P, Sackett DL, Kang YK, Zhan Z, Buters JT, Fojo T, Poruchynsky MS. Paclitaxel-resistant human ovarian cancer cells have mutant beta-tubulins that exhibit impaired paclitaxel-driven polymerization. J Biol Chem. 1997;272:17118-17125.

119. Nicoletti MI, Valoti G, Giannakakou P, Zhan Z, Kim JH, Lucchini V, Landoni F, Mayo JG, Giavazzi R, Fojo T. Expression of beta-tubulin isotypes in human ovarian carcinoma xenografts and in a sub-panel of human cancer cell lines from the NCI-Anticancer Drug Screen: Correlation with sensitivity to microtubule active agents. Clin Cancer Res. 2001;7:2912-2922. 
120. Rowinsky EK, Donehower RC. Paclitaxel (Taxol). N Engl J Med. 1995;332:1004-1014.

121. Guminski AD, Harnett PR, deFazio A. Carboplatin and paclitaxel interact antagonistically in a megakaryoblast cell line - a potential mechanism for paclitaxel-mediated sparing of carboplatin-induced thrombocytopenia. Cancer Chemother Pharmacol. 2001;48: 229-234.

122. Takimoto $\mathrm{CH}$, Rowinsky EK. Dose-intense paclitaxel: deja vu all over again? J Clin Oncol. 2003;21:2810-2814.

123. Markman M, Kennedy A, Webster K, Kulp B, Peterson G, Belinson J. Paclitaxel-associated hypersensitivity reactions: Experience of the gynecologic oncology program of the Cleveland Clinic Cancer Center. J Clin Oncol. 2000;18:102-105.

124. Lee JJ, Swain SM. Peripheral neuropathy induced by microtubulestabilizing agents. J Clin Oncol. 2006;24:1633-1642.

125. Arbuck SG, Strauss H, Rowinsky E, et al. A reassessment of cardiac toxicity associated with Taxol. J Natl Cancer Inst Monogr. 1993: $117-130$.

126. Gianni L, Vigano L, Locatelli A, et al. Human pharmacokinetic characterization and in vitro study of the interaction between doxorubicin and paclitaxel in patients with breast cancer. J Clin Oncol. 1997;15: 1906-1915.

127. Gianni L, Munzone E, Capri G, et al. Paclitaxel by 3-hour infusion in combination with bolus doxorubicin in women with untreated metastatic breast cancer: high antitumor efficacy and cardiac effects in a dose-finding and sequence-finding study. J Clin Oncol. 1995; 13:2688-2699.

128. Holmes FA, Madden T, Newman RA, et al. Sequence-dependent alteration of doxorubicin pharmacokinetics by paclitaxel in a phase I study of paclitaxel and doxorubicin in patients with metastatic breast cancer. J Clin Oncol. 1996;14:2713-2721.

129. Sparano JA, Speyer J, Gradishar WJ, et al. Phase I trial of escalating doses of paclitaxel plus doxorubicin and dexrazoxane in patients with advanced breast cancer. J Clin Oncol. 1999;17:880-886.

130. Jerian S, Keegan P. Cardiotoxicity associated with paclitaxel/trastuzumab combination therapy. J Clin Oncol. 1999;17:1647-1648.

131. Seewaldt VL, Cain JM, Goff BA, Tamimi H, Greer B, Figge D. A retrospective review of paclitaxel-associated gastrointestinal necrosis in patients with epithelial ovarian cancer. Gynecol Oncol. 1997;67: 137-140.

132. Pestalozzi BC, Sotos GA, Choyke PL, Fisherman JS, Cowan KH, O'Shaughnessy JA. Typhlitis resulting from treatment with taxol and doxorubicin in patients with metastatic breast cancer. Cancer. 1993;71:1797-1800.
133. Feenstra J, Vermeer RJ, Stricker BH. Fatal hepatic coma attributed to paclitaxel. J Natl Cancer Inst. 1997;89:582-584.

134. Hoff PM, Valero V, Holmes FA, Whealin H, Hudis C, Hortobagyi GN. Paclitaxel-induced pancreatitis: A case report. J Natl Cancer Inst. 1997;89:91-93.

135. Fader AN, Rose PG. Abraxane for the treatment of gynecologic cancer patients with severe hypersensitivity reactions to paclitaxel. Int $J$ Gynecol Cancer. 2009;19:1281-1283.

136. Desai N, Trieu V, Yao Z, et al. Increased antitumor activity, intratumor paclitaxel concentrations, and endothelial cell transport of cremophorfree, albumin-bound paclitaxel, ABI-007, compared with cremophorbased paclitaxel. Clin Cancer Res. 2006;12:1317-1324.

137. Blum JL, Savin MA, Edelman G, et al. Phase II study of weekly albumin-bound paclitaxel for patients with metastatic breast cancer heavily pretreated with taxanes. Clin Breast Cancer. 2007;7: $850-856$

138. Rizvi NA, Riely GJ, Azzoli CG, et al. Phase I/II trial of weekly intravenous 130-nm albumin-bound paclitaxel as initial chemotherapy in patients with stage IV non-small-cell lung cancer. $J$ Clin Oncol. 2008;26:639-643.

139. Teneriello MG, Tseng PC, Crozier M, et al. Phase II evaluation of nanoparticle albumin-bound paclitaxel in platinum-sensitive patients with recurrent ovarian, peritoneal, or fallopian tube cancer. $J$ Clin Oncol. 2009;27:1426-1431.

140. Harries M, O’Donnell A, Scurr M, et al. Phase I/II study of DHApaclitaxel in combination with carboplatin in patients with advanced malignant solid tumours. Br J Cancer. 2004;91:1651-1655.

141. Sabbatini P, Sill MW, O'Malley D, Adler L, Secord AA. A phase II trial of paclitaxel poliglumex in recurrent or persistent ovarian or primary peritoneal cancer (EOC): A Gynecologic Oncology Group Study. Gynecol Oncol. 2008;111:455-460.

142. Regina A, Demeule M, Che C, et al. Antitumour activity of ANG1005, a conjugate between paclitaxel and the new brain delivery vector Angiopep-2. Br J Pharmacol. 2008;155:185-197.

143. Trimble EL, Adams JD, Vena D, et al. Paclitaxel for platinumrefractory ovarian cancer: Results from the first 1,000 patients registered to National Cancer Institute Treatment Referral Center 9103 J Clin Oncol. 1993;11:2405-2410.
International Journal of Women's Health

\section{Publish your work in this journal}

The International Journal of Women's Health is an international, peerreviewed open-access journal publishing original research, reports, reviews and commentaries on all aspects of women's healthcare including gynecology, obstetrics, and breast cancer. Subject areas include: Chronic conditions (migraine headaches, arthritis, osteoporosis);

\section{Dovepress}

Endocrine and autoimmune syndromes; Sexual and reproductive health; Psychological and psychosocial conditions. The manuscript management system is completely online and includes a very quick and fair peer-review system. Visit http://www.dovepress.com/ testimonials.php to read real quotes from published authors. 